Portland State University

PDXScholar

$5-19-1978$

\title{
An Analysis of Sex Role Bias in Clinician's Evaluations of Client Behavior
}

Shari Paula Greenberg

Portland State University

Follow this and additional works at: https://pdxscholar.library.pdx.edu/open_access_etds

Part of the Clinical and Medical Social Work Commons, Gender, Race, Sexuality, and Ethnicity in Communication Commons, and the Social Work Commons Let us know how access to this document benefits you.

\section{Recommended Citation}

Greenberg, Shari Paula, "An Analysis of Sex Role Bias in Clinician's Evaluations of Client Behavior" (1978). Dissertations and Theses. Paper 2859.

https://doi.org/10.15760/etd.2853

This Thesis is brought to you for free and open access. It has been accepted for inclusion in Dissertations and Theses by an authorized administrator of PDXScholar. Please contact us if we can make this document more accessible: pdxscholar@pdx.edu. 
AN ABSTRACT OF THE THESIS OF Shari Paula Greenberg for the Master of Social Work presented May 19, 1978.

Title: An Analysis of Sex Role Bias in Clinicians' Evaluations of Client Behavior.

APPROVED BY MEMBERS OF THE THESIS COMMITTEE:

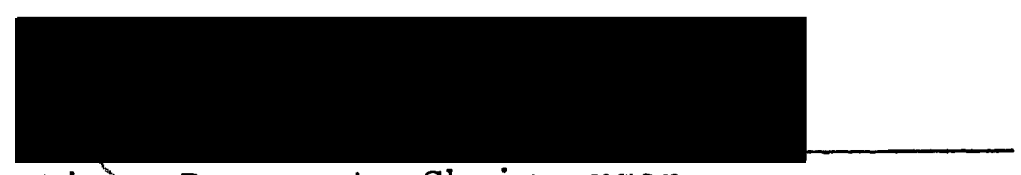

Diante Pancoast, Chairperson

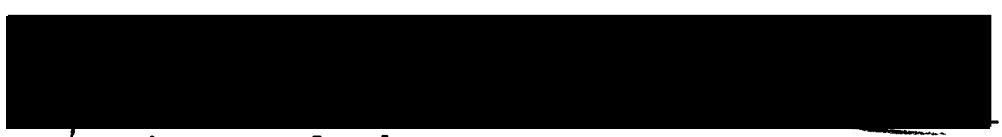

Quentin D. Clarkson

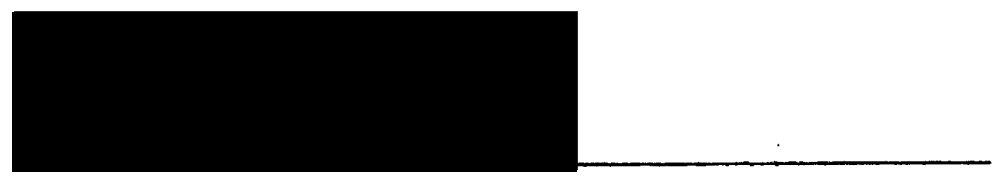

Pamela Munter

This study investigated the effects of sex differences on clinical judgements. It was hypothesized that: 1) clinicians will respond differently to aggressive, selfassertive, or dependent behavior, depending upon whether this behavior was performed by a man or a woman; 2) clinicians will have different treatment goals for a man and a woman who behaved in the same manner; 3) clinicians will describe the client engaged in aggressive, selfassertive, or dependent behavior differently, depending on 
the sex of the client; 4) clinicians will have different feelings towards men and women behaving in exactly the: same manner, and; 5) clinicians will rate aggressive women and dependent men as more emotionally disturbed and, as such, in need of longer and more intensive treatment than dependent women and aggressive men.

The subjects consisted of a random sample of 16 psychologists and 16 social workers from the Portland metropolitan area: 16 males and 16 females. Each clinician was asked to read three vignettes, one depicting self-assertive behavior, one depicting aggressive behavior, and one depicting dependent behavior. The gender of the client and the order of the vignettes remained constant. Half of the male social workers and psychologists were given male stimuli and half were given female stimuli. The same procedure was followed with female social workers and psychologists. All questionnaires were returned.

In summary, clinicians tended to perceive their clients, especially clients acting aggressively, in a stereotyped manner. While the results were not as conclusive, they also had different responses to and different feelings about a client's behavior depending upon the sex of the client. Clinicians did not appear to have different treatment goals for or different judgements about men and women behaving in the same manner. 
A major implication of these findings is that even though clinicians reveal their biases by their different perceptions of and feelings about men and women acting aggressively, self-assertively, and dependently, that they do not necessarily translate these biases into prejudicial treatment in the counseling interview. 


\title{
AN ANALYSIS OF SEX ROLE BIAS IN CIINICIANS' EVALUATIONS OF CLIENT BEHAVIOR
}

\author{
by
}

\section{SHARI PAULA GREENBERG}

A thesis submitted in partial fulfiliment of the requirements for the degree of

\author{
MASTER \\ of \\ SOCIAL WORK
}

Portland State University

1978 
TO THE OFFICE OF GRADUATE STUDIES AND RESEARCH:

The members of the Committee afprove the thesis of Shari Paula Greenberg presented May 19, 1978.

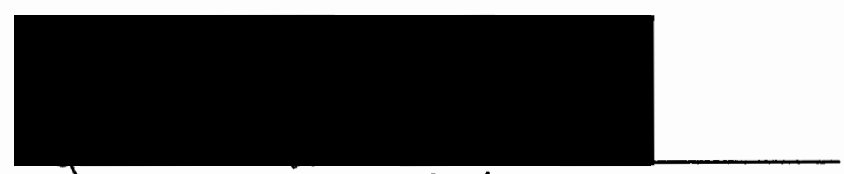

Diane Pancoast, Chairperson

Quentin D. Clarkson

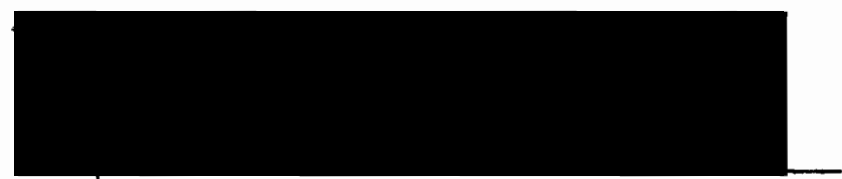

Pamela Munter

APPROVED:

Bernard Ross, Head, Department of Social Work

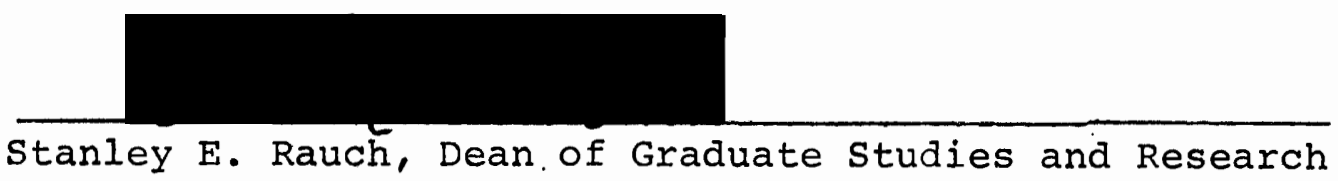


TABLE OF CONTENTS

PAGE

IIST OF TABLES

v

CHAPTER

I INTRODUCTION . . . . . . . . . . . 1

II REVIEW OF THE IITERATURE . . . . . . . . 3

III DESCRIPTION OF THE PROBLEM . . . . . . . 14

IV METHODS AND TECHNIQUES . . . . . . . . 17

Instrument Development . . . . • 17

Content of the Instrument . . . . . 23

Selection of subjects . . . . . . 26

V DATA ANALYSIS . . . . . . . . . . 28

VI RESULTS . . . . . . . . . . . . 30

VII SUMMARY .............. 63

VIII DISCUSSION • . . • • • • • • • • • 66

Trends in the Data........ . 66

Implications for Counselor Training

programs ............ 68

Directions for Further

Research ........... 70 
A LIST OF WORKS CONSULTED . . . . . . . . . . 72 APPENDICES

A. Counselor Response Categories . . . . . 81

B. The Questionnaire ........... 83 


\section{LIST OF TABLES}

TABIE

PAGE

I Experimental Design. . . . . . . . 21

II Instrument Design . . . . . . . . . . . 31

II Means of Variable 17 from Item 5 in the

Response Section of Aggressive

Vignette. . . . . . . . . . . . 44

IV Means of Variable 21 from Item 5 in the

Response Section of the Aggressive

Vignette . . . . . . . . . . . 44

$\mathrm{V}$ Means of Variable 17 from Item 3 in the

Goal Section of the Self-Assertive

Vignette . . . . . . . . . . . 45

VI Means of Variable 20 from Item 3 in the

Goal Section of the Self-Assertive

Vignette . . . . . . . . . . . 45

VII Means of Variable 21 from Item 3 in the

Goal Section of the Self-Assertive

Vignette . . . . . . . . . . 46

VIII Means of Variable 21 from Item 1 of the

Adjective Checklist of the Aggres-

sive Vignette . . . . . . . . . . .

IX Means of Variable 17 from Item 2 of the

Adjective Checklist of the Aggres-

sive Vignette. . . . . . . . . 48 
$\mathrm{X}$ Means of Variable 18 from Item 2 of the Adjective Checklist of the Aggressive Vignette . . . . . . . . . .

XI Means of Variable 21 from Item 2 of the Adjective Checklist of the Aggressive Vignette . . . . . . . . . .

XII Means of Variable 18 from Item 6 of the Adjective Checklist of the Aggressive Vignette • . . . . . . . . .

XIII Means of Variable 18 from Item 8 of the Adjective Checklist of the Aggressive Vignette . . . . . . . . 50

XIV Means of Variable 21 from Item 9 of the Adjective Checklist of the Aggressive Vignette. . . . . . . . . . .

XV Means of Variable 18 from Item 10 of the Adjective Checklist of the Aggressive Vignette . . . . . . . . . . . .

XVI Means of Variable 18 from Item 13 of the Adjective Checklist of the Aggressive Vignette . . . . . . . . . .

XVII Means of Variable 18 from Item 16 of the Adjective Checklist of the Aggressive Vignette . . . . . . . . . . . 
vii

TABLE

PAGE

XVIII Means of Variable 18 from Item 18 of the Adjective Checklist of the Aggressive Vignette. • • • . . . . . • •

XIX Means of Variable 20 from Item 16 of the Adjective Checklist of the Aggressive Vignette. . . . . . . . . . 54

$\mathrm{XX}$ Means of Variable 21 from Item 16 of the Adjective Checklist of the Aggressive Vignette. • . . . . . . . 54

XXI Means of Variable 16 from Item 18 of the Adjective Checklist of the Aggressive Vignette . . . . . . . . . 55

XXII Means of Variable 21 from Item 18 of the Adjective Checklist of the Aggressive Vignette . . . . . . . . .

XXIII Means of Variable 18 from Item 2 of the Adjective Checklist of the SelfAssertive Vignette . . . . . . . 56 XXIV Means of Variable 21 from Item 2 of the Adjective Checklist of the SelfAssertive Vignette . . . . . . 56 XXV Means of Variable 18 from Item 10 of the Adjective Checklist of the SelfAssertive Vignette . . . . . . . . 
XXVI Means of Variable 21 from Item 10 of the Adjective Checklist of the SelfAssertive Vignette . . . . . . . . 57

XXVII Means of Variable 21 from Item 14 of the Adjective Checklist of the selfAssertive Vignette . . . . . . . 58 XXVIII Means of Variable 18 from Item 18 of the Adjective Checklist of the SelfAssertive Vignette . . . . . . . .

XXIX Means of Variable 21 from Item 18 of the Adjective Checklist of the SelfAssertive Vignette . . . . . . . . 59 Xxx Means of Variable 21 from Item 5 of the Adjective Checklist of the Dependent Vignette . . . . . . . . . . 60 XXXI Means of Variable 21 from Item 10 of the Adjective Checklist of the Dependent Vignette • • • • • • • • • • 60 XXXII Means of Variable 18 from Item 11 of the Adjective Checklist of the Dependent Vignette . . . . . . . . . 61 XXXIII Means of Variable 21 from Item 3 of the Iast Page of the Aggressive Vignette • • • • • • • • • • • • • • 
XXXIV Means of Variable 16 from Item 4 on the

Last Page of the Self-Assertive

Vignette . . . . . . . . . 62 


\section{CHAPTER I}

\section{INTRODUCTION}

In recent times, there has been controversy regarding the inadequacy of existing counseling methods in dealing with the complex needs and conflicts of modern women (Chesler, 1972; Fabrikant, 1974).

The American Psychological Association's "Report of the Task Force on Sex Bias and Sex Role Stereotyping in Psychotherapeutic Practice" outlined two major areas of concern with regards to sexism in psychotherapy. The first was the question as to how a therapist's values and attitudes effect the process of psychotherapy. The second area of concern was the therapist's knowledge of psychological processes in women. This study concerned itself with the issue of the therapist's values and attitudes, and how these values and attitudes might effect the clinician's behavior: in the counseling interview.

This researcher took the position that it is extremely important for a therapist to be aware of his own attitudes, values, and biases, so that he will not impose them on his client. Concomitantly, he is responsible for understanding how his values may or may not facilitate the mental health of the person whom he is counseling. It has been empirically demonstrated that most clinicians 
expect women to be more passive and dependent, while simultaneously admitting that these traits do not describe the healthy adult personality (Broverman, et. al., 1972; Fabrikant, 1974). Therapists need to be aware of the ways in which conventional stereotypes influence their own behavior and attitudes in a therapeutic relationship. of note is the fact that there are only a few good process studies of sex bias and sex role stereotyping in the therapeutic process, however, there are several good studies on clinical judgement which are very thought. provoking. The literature review will concentrate mainly on studies of clinical judgement. 
CHAPTER II

\section{LITERATURE REVIEW}

This literature review will demonstrate that the research results are equivocal with regard to the biasing effects of clinician and client sex. First, several studies which revealed significant bias will be presented. Then some studies in which gender and attitude were not significant will be discussed. Lastly, the two studies that had the most significant impact on the development of this research will be evaluated in more detail.

While reviewing these studies, several considerations should be kept in mind. One is whether or not clinicians have a certain role ideal for men and women, and if they do, how do they implement these role expectations in the therapeutic process? secondly, many of the studies to be discussed fail to address themselves to the question of how biased attitudes are translated into different clinician behavior towards males and females. In addition, one can ask how do clinicians view the mentally healthy woman. Finally, has the recent popularity of research in sex differences helped to modify traditional views of mental health in women?

Parker (1967) investigated the issue of therapist dominance. He found that women clients were given a 
higher proportion of non-directive responses than men. Oleski \& Balten (1972) explored the role of sex differences in the empathic process. They found no significant difference in empathic ability between males and females. Yet, they found evidence to support the hypothesis that people have more empathy when judging people of the same sex.

Female counselors and educators were more likely to approve of women's nonfamilial orientations than their male counterparts (Naffziger, 1972). A study by Friedesdorf (cited in Schlogsberg \& Pietrofesa, 1973) revealed that women professionals who evaluated a college bound high school girl, represented by a strong Vocational Interest Blank, saw the girl as aspiring to careers which required a college education, whereas their male counterparts saw her as more intrigued with traditional semiskilled feminine jobs.

Schlossberg and Pietrofesa (1973) reviewed several articles on counselor bias, specifically with regards to vocational counseling, which gave evidence for a double standard of mental health. They then proposed a training model designed to teach counselors to deal with their clients in an unbiased manner.

Haan and Iuvson (1973) found that women psychologists saw their women clients as more intelligent, competent, and self-accepting than male psychologists saw 
them. The male psychologists tended to see their women clients in a much more conventional manner, emphasizing their sensitivity and social responsiveness. The male psychologists evaluated their own sex more critically than female psychologists did in that they focused on their male clients passivity and self-doubt.

Two studies utilizing the Thematic Apperception Test (TAT) revealea thát the sex of the subject influenced clinician evaluations. In both investigations women were given more TAT cards of all types by clinicians than men (Masling \& Harris, 1969).

Collins and sedlacek (1974) reported that female clients were more frequently seen as having emotionalsocial conflicts whereas male clients were viewed as having vocational-educational problems. In addition, females were more likely to be given an appointment than males. In the same vein, a study by Abramowitz, Abramowitz, Roback, \& McKee (1974) noted that women were more often seen for counseling at a psychiatric clinic than men.

The female client was described as healthier than the male patient in a case analogue study (Miller, 1974) in which passivity was viewed as the most significant clinical factor. In addition, the major goal of treatment was not judged to be passivity when the client was a woman. Social workers, in contradistinction to psychiatrists and 
psychologists, more frequently recommended a supportive approach for the female and an insight oriented approach for the male.

Hill (1975) examined how the sex of the client and the sex of the counselor effected behavior in the clinical interview. She had twelve male and twelve female counselors, half inexperienced, each of whom had recorded their second counseling session with a client. She found that same sexed pairings produced more discussion of feelings by both the counselor and the client. She also found that inexperienced males and experienced female counselors were more active and empathic, eliciting more feelings from their clients than their counterparts.

In a similar study Fernoff (1975) had ninety-nine subjects view films of counseling sessions. She reported that female patients received warmer responses from all therapists than males. She found no difference between male and female therapists with regard to accurate empathy, non-possessive warmth, and general responsiveness. Yet there were differences in how the therapists rated their own responses. Female therapists described themselves as experiencing more difficulty in dealing with the client on a subjective level than the male therapists.

Therapist attitudes may be changing, however, as two studies by Fabrikant (1.97.4) imply. Responses 
made by clinicians on a questionnaire revealed some of the following attitudes:

1. Women can have a full life even if they are not married.

2. Women need more than a wife/mother role in order to fulfill themselves.

The second study, which essentially repeated the first, revealed that norms appear to be changing in the area of male/female description. This study utilized a list of questions and words describing sex-role traits. In the first study male therapists rated $71 \%$ of the female words negatively and $71 \%$ of the male words positively. Female therapists rated $68 \%$ of the female words as negative and $67 \%$ of the male words as positive. While the second study revealed that the female is still seen in a negative manner, there was some movement in a positive direction. In adition, several positive characteristics changed from male to equal, while some of the negative characteristics went from feminine to equal. This data gives some support to the notion that the therapist's attitudes towards appropriate sex roles may be changing.

There were fewer studies in which counterstereotypic biases were found. Two will be discussed. A study by Abramowitz, Abramowitz, Jackson, \& Gomes (1973) investigated sex and political ascriptions by giving a spurious case report of a college student in which the sex was factorially varied to seventy-one male and female 
masters level counselors. Their results showed that female examiners were significantly more harsh in their clinical decisions about the female student than their male counterparts.

Chasen (1974) also reported finding. counterstereotypic bias among school psychologists. Specifically, male psychologists with non-traditional sex-role attitudes obtained counterstereotypic scores on an instrument he designed to measure bias. Yet Mann (1974) reported that mental health professionals made less severe diagnostic ratings when judging a member of the same sex.

There were several studies in which the sex of the counselor and the sex of the client were not significant and, or the results were conflicting. Williams (1969) found that the sex of the interviewer was significantly related to the verbal production of the client on two out of four interview questions. Yet the sex of the interviewer did not apparently have an effect on verbal conditioning or the subject's perception of the interviewer.

It was not clear from Thomas and Stewart's (1971) results whether or not a female client receives "better" counseling from a female clinician. Even though female secondary school counselors manifested more approval than males of both sex-role deviant and sex-role congruent girls, similar differences were not found with regards to career appropriateness or need for further counseling. 
Concurrently, female counselors judged the nonconforming girls as more in need of counseling than their conventional peers, a trend accounted for mostly by the responses of the less experienced female counselors.

Coie, Pennington, and Buckley (1974) studied the effects of situational stress, as well as sex roles, on college studentst evaluations of psychopathology. They found no evidence of global prejudices against females.

In an analogue study (Lewittes, Moselle, \& Simmons, 1973) utilizing a male or female version of a Rorschach protocol, where the respondents listed a moderate degree of confidence in their evaluations of pathology, diagnosis, and level of intellectual functioning, clinical bias due to patient sex alone was not found. Staten (1974) concluded that neither gender nor sex-role attitudes of the counselor account for the change of female client's sex-role attitudes. This occurred even though male counselors did discuss assertiveness and decision-making more often than female counselors.

Zeldow (1975) investigated in two separate studies the hypothesis that evaluations of psychiatric disturbance were effected by the sex of the patient and the sex of the judge. In the first study fifty male and fifty female college students judged self-disclosing statements that were ascribed to seriously disturbed psychiatric 
patients of both sexes. Sex of the patient or judge did not effect the respondents' evaluations of emotional disturbance. In the second study the same results were found when eighty clinically trained subjects evaluated eight case studies for degree of disability, need for psychological intervention, and prognosis.

After reviewing the methodologies of the previous studies this researcher considered replicating shapiro's (1975) study of prejudicial behavior in the counseling interview with a larger sample consisting of practicing social workers, psychologists, and psychiatrists.

Shapiro (1975) investigated the assumption that sex-role bias in clinicians' attitudes towards women were automatically translated into prejudicial behavior in the actual counseling situation.

Shapiro's sample consisted of sixteen counseling trainees at Stanford University. She videotaped their initial interviews with clients who were confederates trained to act in traditional and nontraditional modes. Her primary concern was counselor differential response to sex-typed client statements. Independent judges then rated the counselors responses to specific cue sentences on the videotape.

Shapiro reported that the results of her study were inconciusive but suggestive. Her interpretation of the data was that counselors might act in a more biased manner 
with traditional rather than non-traditional female clients. This situation, she suggested, might be a reflection of changing norms which describe the ideal women. In essence, she posited that females who exhibited more traditionally masculine behaviors were more positively valued by counselors. She also found that female counselors were less behaviorally biased and that they more actively reinforced astereotypic client verbal behavior. In summary, shapiro reported that she found no reliable indices of actual counselor behavioral bias in counselor sex-role attitudes, in the counselor's perception of the client, or in the client's perception of the counselors.

This researcher concurs with Shapiro, when Shapiro said that, ultimately, how a counselor actually behaves is considerably more important than how he say he behaves. However, it is questionable as to whether the instrument in her study was able to adequately measure counselor bias. A major problem with the instrument, that Shapiro acknowledged, was that it only coded responses to specific client cue statements. This ignored counselor initiations and counselor responses to noncue client statements. Even though she had excellent rationales for limiting her coding in this manner it might have affected the validity of her findings.

Secondly, as Shapiro suggested, in order to warrant 
the generalizability of the data, future studies would do well to test her hypothesis with larger sample spaces and a more geographically varied population.

Thirdly, crucial to the understanding of her findings would be the experimental validation of the relationships between client verbal behavior, client self-image, and actual client behaviors outside of the clinical interview.

Lastly, the meaning of Shapiro's findings might be clarified by a more thorough understanding of how using specific role-play situations might have elicited more counselor bias towards typical clients. Shapiro suggested that more crisis oriented situations might influence counselors to encourage a traditional response.

The research which greatly influenced this study was called "When Stereotypes Hurt: Three Studies of Penalties for Sex-Role Reversals" (Costrick, et al. 1975). One of the findings in these studies was that dependent men were liked significantly less than dependent women. Aggressive and assertive women were evaluated negatively on indices of liking and psychological adjustment. The results showed that men were given no more room to deviate from their stereotypic roles than women.

For the most part, it was the methods utilized in Costrich's study that were of great interest to this researcher rather than the results. Therefore, a detailed 
discussion of the methodology in these studies and how it influenced the development of this research will be found in the chapter on methods. 
CHAPTER III

DESCRIPTION OF THE PROBLEM

The primary purpose of this study was to investigate the possibility that clinicians act as unwitting norm enforcers, specifically, that they reinforce sex-role stereotypes. The fact that professional practice is growing rapidly in the absence of much evidence that it is performing its overt purpose, the alleviation of psychological distress, leads some researchers to surmise (Hurvitz, 1973, Szasz, 1961, 1965, 1970, 1971) that more fundamental, covert purposes are being served. Some researchers suggest that psychotherapy can perform a moral resocialization function (Hurvitz, 1973), meaning that same elients who change tend to adopt the therapists values (e.g. Rosenthal, 1955).

The present study is primarily concerned with the possible bias in the drawing of clinical inference. Abramowitz, et. al. (1973) extensive review of the literature on clinical judgement yielded considerable evidence that, if value-biases in clinical judgement did indeed exist, that the most likely attributes to investigate would be client social class, race, life-style, psychiatric label, political orientation, and sex role. With regard to the psychotherapists themselves, the important variables 
seemed to include personal and professional characteristics, including such things as sex, experience, race, and values.

Previously, clinical bias had been most consistently correlated with clinician values and client label, social class, and life style.

Since previous research results were equivocal with regards to the biasing effects of client and clinician sex and of clinician experience (Abramowitz, et. al., 1973) this seemed to be an important area to reinvestigate with special emphasis on how the methodology in this area might be refined.

\section{Research Hypotheses}

The first hypothesis to be investigated was that clinicians would respond differently to aggressive, selfassertive, or dependent client behavior, depending upon whether this behavior was performed by a man or a woman.

The second hypothesis to be investigated was that clinicians would have different treatment goals for a man and a woman who exhibited aggressive,' self-assertive, and, dependent behavior.

The third hypothesis was that clinicians would describe the person engaged in aggressive, assertive, or dependent behavior differently contingent upon whether the client was male or female. This would lend credence to the 
notion that a clinician's perceptions of behavior are filtered through his or her value systems.

The fourth hypothesis stated that clinicians would have different feelings towards men and women who were behaving in an aggressive, assertive, or dependent manner. More specifically, it was surmised that clinicians would be more uncomfortable around clients who violated sexrole stereotypes.

The fifth hypothesis to be investigated was that clinicians would see aggressive women and dependent men as more emotionally disturbed and as such in need of longer and more intensive treatment than dependent women and aggressive men. 
CHAPTER IV

METHODS AND TECHNIQUES

Instrument Development

Initially, this researcher considered the possibility of doing a process study in which clinical interviews would be videotaped. These interviews would then be rated by independent judges looking for evidence of clinicians behaving in ways which reinforced sex-role stereotypes. This kind of design had the advantage of taking into account secondary, nonverbal expressive cues. Probably, the most reliable way of determining the real attitudes and behavior of clinicians would be to observe and assess their reactions to clients over a considerable period of time. This prolonged study could take into account the clinician's use of words, personal mannerisms, and other, very difficult to measure, variables.

However, due to the time and expense involved in conducting a process study, as well as the difficulty in convincing clinicians to participate in such time consuming research, this researcher decided upon a design utilizing a written questionnaire.

There were several advantages to using a written vignette.

First, using a written vignette guaranteed that all 
clinicians would be responding to the same stimuli. Costrich (1975) suggested that one could eliminate the possibility that a confederate overacted (i.e., that the woman read her script in a more aggressive manner and the man in a more passive manner). This overacting might have influenced the subject's judgement. This overacting is eliminated by providing the respondent with identical written dialogue that is either attributed to a man or a woman. Secondly, researchers have demonstrated that there is a substantial relationship between the kinds of responses counselors make in actual counseling interviews and the type of responses made in testing situations. Test results were shown to be better indicators of actual behavior in counseling interviews than were self-ratings, supervisors' ratings, comments made by subjects and supervisors, and observations by the experimenter (Porter 1943, Chase 1946, Hopke 1955).

The development of the instrument used in this study and the research design was most heavily influenced by Costrich et al. (1975). The influence of Marecek's study, one of the three studies on sex-role reversals, on the development of the instrument utilized in this research will now be discussed.

In Marecek's study a booklet of ten psychotherapy vignettes was used. There were four vignettes manifesting expressions of dependence on the therapist, four vignettes 
manifesting expressions of aggression toward the therapist, and two filler items. Each vignette included a statement by the patient to the therapist, and each included information regarding the sex and age of the client. Marecek constructed the two forms of the vignette, with the only difference between them being the stated sex of the clientcommunicator in each vignette. In each form, the order of the vignettes was counterbalanced, and the aggressive and dependent communications were equally divided by sex.

This researcher felt that if clinicians were presented with examples of women or men both acting in aggressive or dependent manners, it would be quite likely that they would consciously or unconsciously discern what the researcher was actually studying, and thus would respond in ways that made them look less biased. In order to ameliarate this situation in this study, each clinician was given a booklet which consisted of three vignettes. The first vignette represented an expression of assertiveness toward the therapist. The secondione represented an expression of aggression towards the therapist. The vignette represented an expression of dependency on the therapist. Each therapist received a booklet with either all male or all female clients. Half of the male social workers and psychologists were given male stimuli and half were given female stimuli half of the female social workers 
and psychologists were given male stimuli and half female stimuli. The order of the vignettes presented to all respondents remained constant (see table I). This research design required that all questionnaires be returned. In retrospect, that requirement created a problem because it took several months to recover the final few of the questionnaires. However, this design also had some advantages. The factorial design enabled the investigator to observe within a single experiment the effect of more than one independent variable on the dependent variable. In addition, the interaction of two or more independent variables on the dependent variable could be studied. The independent variables will be delineated when the results of this study are discussed.

In developing the instrument for this study, this researcher paid particular attention to the research recommendations made by Costrich et al. (1975), especially with regards to using a written script. In their second study, they prepared a tape representing passive and aggressive behavior in which half the time the speaker was a woman, and in which half the time the speaker was a man. Each subject listed to one version of the tape and then rated the stimulus person (i.e. the student in a studentcounselor interaction in which the student was either passive or aggressive) on a series of seven-point differential items which included behavioral descriptions. The 
TABLE I

EXPERIMENTAL DESIGN

\begin{tabular}{|c|c|c|}
\hline & Psychologists & Social Workers \\
\hline \multirow{3}{*}{ Male } & Subjects & Subjects \\
\hline & Male & Male \\
\hline & Female 4 & Female \\
\hline$m=10$ & Male & Male \\
\hline & Female 4 & Female \\
\hline
\end{tabular}


results of this study indicated that an aggressive woman was seen as more dominant than an aggressive man. The more dominant a woman seemed, the more she needed therapy. The problem with this design is that it is impossible to determine whether or not the results are due to the fact that the woman read her script in a more aggressive tone. In order to eliminate the problem Fernstein recommended that a written dialogue be used where the statement is attributed to either a man or a woman.

Marecek's vignettes's were followed by questions which asked subjects to describe, for example, how comfortable they felt when interacting with a particular client. In her discussion section she commented that, perhaps, the judgements she had asked the respondents to make were too abstract and that she might have found more significant effects, if she had asked how they would respond to a client.

However, it seemed questionable to this researcher that a clinician's self-report regarding his responses to and feelings about dealing with aggressive and dependent men and women would be a reliable indicator of bias in a counseling relationship. First, a clinician's self-report and his actual behavior may be different. Second, clinicians are trained to be aware of their own biases, and consequently their biases or feelings may not significantly change the way they would respond in the therapeutic inter- 
view. Since there were potential problems already identified with the measure designed to determine a clinician's response to a client, it seemed advisable to also ask the clinicians to describe the behavior they encountered in each vignette. This had the aim of seeing whether they described the exact same behaviors manifested by men and women differently. With this added information it would be possible to compare clinicians' descriptions of behavior with their responses to it. In other words, the possibility was explored that even though clinicians perceived behavior differently, as evidenced by their behavior descriptions, they did not necessarily respond differently as a result. The behavior descriptions were taken from the most relevant eighteen adjectives contained in the checklist from the seven-point semantic differential items in the instrument used by the Broverman study (1972).

Content of the Instrument

The questionnaire consisted of a cover letter, a section for the identifying information on the respondent, and three vignettes representing aggressive, self-assertive, and dependent behavior.

In the cover letter, the respondents were told that the purpose of the questionnaire was to investigate the kinds of responses that clinicians have towards their 
clients. It seemed inadvisable to give direct permission to feel negatively about a client as Marecek had done since this might bias the answers in a negative direction. Consequently, it was simply stated that responses would not be judged on a right or wrong basis.

The second page of the questionnaire consisted of identifying information. Each clinician was asked about his age, sex, marital status, theoretical orientation, educational background, and level of experience. This information was obtained in order to determine if any of these variables would correlate highly with clinicians' responses to the vignettes.

Each vignette was followed by four measures. The first asked the clinician how he or she would respond in each hypothetical clinical situation by rating broad response categories on Likert-type scales. The second asked the clinician to rate on Likert-type scales his goals for treatment in each clinical situation. In the third section the clinician was asked to describe the behavior he encountered on eighteen seven-point semantic differential items. The last section asked him to rate on Likert-type scales his feelings about the client, his difficulty in responding to the client, and his judgement about the seriousness of the client's problem (see appendix B).

The first major task in developing this instrument 
was to design the vignettes. This process occurred in several stages.

First, many practicing clinicians were asked to give examples of aggressive, assertive, and dependent behaviors which they had experienced in actual clinical situations. These examples were tape recorded and then transcribed. From all the examples received, eighteen vignettes, which consisted of six aggressive, six self-assertive, and six dependent behaviors, were presented to a random sample of first year Social Work graduate students at Portland state University. These students were asked to describe the behaviors they encountered in each vignette. The three psychotherapy vignettes which were most often described as aggressive, assertive, and dependent were used in the instrument for this research.

The first pre-test was given to a random sample of first year graduate students at the School of Social Work in the fall of 1974. The questionnaire they received consisted of a cover letter, the identifying information of the respondent, the three'vignettes, and a question following each vignette. The question asked them to write down how they would respond to each particular client behavior. The responses were then rated utilizing Porter's definitions of counselor response categories (see appendix A). This first pre-test convinced this researcher of the extreme difficulty of attempting a content analysis of 
open ended responses with the aim of ferretting out possible counselor biases. Instead, the responses were utilized to help construct examples of the major kinds of responses a counselor might make in each specific situation.

In the final form of the instrument there were five responses to each vignette intended to represent evaluative, interpretive, probing, understanding, and supportive approaches to the client. The final form of the instrument was administered to first year graduate students at the School of Social Work in order to ferret out any possible problems. Since no problems were apparent the questionnaire was mailed to the clinician sample in January of 1975 .

\section{Selection of subjects}

Much of the research done in the area of sex-role stereotyping has been done with undergraduate students as subjects. Since clinicians often have some training designed to facilitate an awaseness of their own values and biases, it seemed reasonable to predict that clinicians could well be less biased than undergraduate students. Since the research design demanded that every questionnaire be returned, the sample population was limited to the Portland metropolitan area so that the possibility of successful follow-up could be maximized. Initially, the clinician population was to include 
male and female psychiatrists, psychologists, and social workers. Since there were only two female psychiatrists within the sample frame, psychiatrists had to be eliminated from the study. Since there were ten licensed women psychologists with Ph.D's in the Portland metropolitan area, psychologists were retained in the study. Thirty-two clinicians were asked to participate in this research. A random sample of eight male and eight female psychologists was taken from a list of licensed clinical psychologists who practiced in the Portland area. The NASW mailing list was utilized to draw a random sample, stratified by sex, of eight male and eight female practicing psychiatric social workers in the Portland area. 
CHAPTER V

DATA ANALYSIS

The data were analyzed by three way analysis of variance (professional group $\mathrm{x}$ sex of respondent $\mathrm{x}$ sex of client or vignette). For each item the following seven tests were conducted:

1. Difference between psychologists and social workers.

2. Difference between male and female therapists.

3. Difference between male and female stimulus.

4. Interaction between group and sex of respondent.

5. Interaction between group and sex of stimulus.

6. Interaction between sex of respondent and sex of stimulus.

7. Three way interaction, group by sex of respondent by sex of stimulus.

Appropriate F statistics were computed. All main effects and interaction effects reported were significant at the .05 level.

Data were collected on the marital status, theoretical orientation, educational background, and experience of the practitioner. However, this researcher decided to delete the analysis of this data from the present study due 
to the fact that exploring the relationship between the sex of the clinician and the sex of the client was an extensive and complicated endeavor in and of itself. The following points should be kept in mind when considering the results of this study. Firstly, behavior is not evaluated or judged, but only presented. Secondly, in an effort to simplify the translation of the data into a readable text the following words will be utilized to designate the magnitude of the differences between means.

1. "Slightly less or more" will mean a difference of less than one interval on the Likert-type scale or semantic differential scale.

2. "More likely" will mean a difference of more than one interval but less than two intervals on either scale.

3. "Much less or more" will refer to a difference of more than two intervals on either scale. 


\section{CHAPTER VI}

\section{RESULTS}

This chapter will be organized in the following manner. First each hypothesis will be stated. Second the items designed to test each hypothesis will be described. Then the significant items will be discussed on each measure for each of the vignettes. (see table II). The order of the vignettes discussed will be as follows; self-assertive, aggressive, and dependent.

For every variable on every item discussed there will be a table presenting the treatment means for each possible combination of sex of respondent, sex of client or vignette, and professional group. The first letter in the three letter sequence in the tables refers to whether the respondent is a social worker (S) or psychologist (P). The second letter in the sequence refers to the sex of the respondent or clinician, male (M) or female (F). Lastly, the third letter in the sequence refers to the sex of the person described in the vignette.

The essential purpose of this study was to determine whether or not clinicians would perceive differently and respond differently to assertive, aggressive, and dependent client behavior, depending upon whether it was exhibited by a man or woman. 


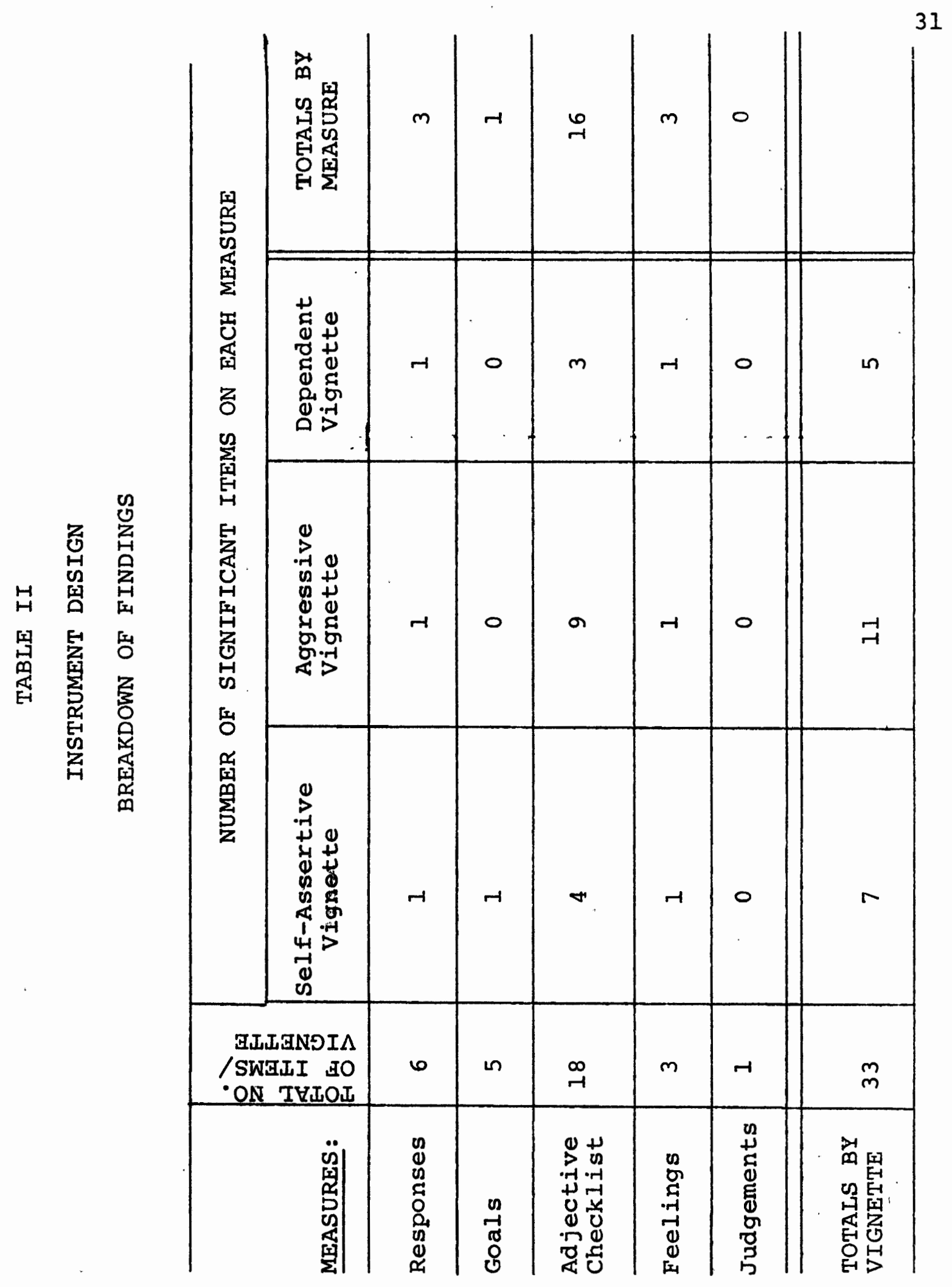




\section{First Hypothesis}

The first hypothesis stated that clinicians would respond differently (i.e. use different response categories), to men and women when they behaved in exactly the same manner whether it be aggressive, self-assertive, or dependent.

The items in the questionnaire which dealt with this hypothesis were prefaced by the statement, "How likely is it that you would make each of the following responses?" Specifically this included the first six items after each vignette. The hypothesis contained several items significant at the .05 level. The significant items will be discussed briefly.

\section{Self-Assertive Vignette}

On item three, defined as the understanding response to self-assertive behavior there was a three way interaction between the group, sex of respondent, and sex of stimulus.

None of the seven factors studied were found to be significant on items one, two, four, five, or six.

\section{Aggressive Vignette}

In the vignette portraying aggressiveness, item five, the probing response which stated, "Is this feeling a very familiar one with you?" revealed a significant 
difference between male and female therapists (see table III) and an interaction effect between the sex of the respondent and the sex of the stimulus (see table IV). More specifically, female therapists were slightly more likely to make a probing response to both men and women dients behaving aggressively. Male therapists were slightly more likely to use a probing response with male clients. Female therapists were more likely to make a probing, response to men acting aggressively than to women. Items one, two, three, four, and six contained no significant variables.

\section{Dependent Vignette}

Item four, the evaluative response to dependent behavior, generated a three way interaction between the group, sex of respondent and sex of stimulus.

\section{Second Hypothesis}

The second hypothesis tested was that clinicians would have different treatment goals for men and women exhibiting the same behavior. The second set of five items following each vignette prefaced by the question, "How likely is it that you would follow each of the following aims in this particular interview?" was formulated to test this hypothesis. This hypothesis had very few items significant at the .05 level. 
Self-Assertive Vignette

Item three, labeled the interpretive response or purpose, contained three factors significant at the .05 level. The statement read, "Help the client to consider that her reaction may be in part due to her own attitudes." The first significant difference was between male and female therapists (see table V). Female therapists were somewhat unlikely to make an interpretive response to men and women exhibiting self-assertive behavior. Male therapists were a little more likely to make an interpretive response to their clients. Secondly, there was an interaction effect between the group and the sex of the respondent (see table VI). Psychologists were slightly more unlikely to make an interpretive response than social workers. Social workers were slightly more unlikely to make an interpretive response to men. Thirdly, an interaction effect was found between the sex of the respondent and the sex of the stimuli (see table VII). Male therapists were slightly more unlikely to make interpretive reuponses to females exhibiting self-assertive behavior than males. Female therapists were slightly more unlikely to make interpretive responses to males who were acting self-assertively.

Aggressive Vignette

There were no variables significant at the .05 level on any 
of the five items in the goal section of the aggressive vignette.

Dependent Vignette

None of the five items in the goal section of the dependent vignette contained any variables significant at the .05 level.

Third Hypothesis

The third hypothesis stated that clinicians would describe clients who behaved in an aggressive, selfassertive, or dependent manner differently depending upon whether a man or a woman engaged in the behavior. The third set of eighteen items following each vignette was intended to test this hypothesis. The questionnaire asked, "Describe how you see this client by marking the appropriate place on the scale", followed by eighteen adjectives. The trend was for clinicians to describe their clients in a stereotyped manner. For example, aggressive men were described, in general, as more aggressive, independent, objective, dominant, rougher, insensitive, and less dependent than aggressive women. More items reached a .05 level of significance for this hypothesis than for any of the others. 
Self-Assertive Vignette

In the vignette describing self-assertive behavior there were four adjectives on the checklist which produced significant differences on one or several of the seven factors. On the independence scale there was a significant difference between male and female stimulus (see Table XXIII) and an interaction effect between the sex of the respondent and the sex of the stimulus (see table XXIV). Both male and female therapists saw the self-assertive man as more independent than the selfassertive woman. More specifically, male therapists saw males acting self-assertively as much more independent than women. Female therapists saw males as slightly more independent than females acting assertively.

A difference between male and female stimulus was found on the awareness scale (see table XXV). Counselors saw men acting assertively as slightly less aware of other people's feelings. In addition, there was an interaction effect between the sex of the respondent and the sex of the stimulus (see table XXVI). Male therapists saw men acting self-assertively as slightly less aware of other people's feelings than women acting similarly. Concomitantly, female therapists saw females acting self-assertively as slightly less aware of other people's feelings than males. 
On the quiet-loud scale an interaction effect between the sex of the respondent and the sex of the stimuhs was found (see table XXVII). Male therapists described male clients as slightly louder when they acted self-assertively than females acting in the same manner. Concurrently, female therapists described female clients acting self-assertively as louder than males acting assertively.

The dependency scale generated a significant difference between male and female stimulus (see table XXVIII) described men acting assertively as slightly less dependent than women. There was also an interaction effect between the sex of the respondent and the sex of the stimulus (see table XXIX). Male therapists described selfassertive males as slightly less dependent than female clients. It is interesting to note that female therapists described self-assertive females as exhibiting slightly less dependence than men. In summary, there were four items that reacted significant at the .05 level out of eighteen.

\section{Aggressive Vignette}

On item one, the scale which described the aggressiveness of the client there was an interaction effect between the sex of the respondent and the sex of the stimulus (see table VIII). Male therapists described both men and 
women as less aggressive than female therapists described them. Male therapists saw women acting aggressively as less aggressive than men acting aggressively. It is interesting to note that female therapists saw males as slightly less aggressive than females when they were both acting aggressively.

The item which described the independence of the client on the adjective checklist was found to have significant differences on three variables. First there was a significant difference between the way that male and female therapists responded (see table IX). Male therapists saw all clients as being slightly more independent than female therapists saw them. A significant difference was also found between male and female stimulus, (see table $x)$ but was explained more fully by the interaction between the sex of the respondent and the sex of the stimulus (see table XI). Female therapists described male and female clients acting aggressively as showing the same amount of independence. Male therapists described male clients as much more independent than female clients.

A significant difference between male and female stimulus was found on the sixth item which described the subjectivity or objectivity of the client (see table XII). All therapists described men as being slightly more objective. The same variable was found to be significant on the submissive-dominant scale (see table XIII). 
Therapists described males acting aggressively as more dominant than females acting aggressively.

An interaction between sex of respondent and sex of stimulus was found on the very gentle-very rough scale (see table XIV). Female therapists described all clients acting aggressively as much rougher than male therapists described them. Both male and female therapists saw men as slightly rougher than women clients.

Significant differences between male and female stimulus were found on several other items on the adjective checklist. Therapists described men acting aggressively as less aware of the feelings of others than women acting aggressively (see Table XV). Therapists also described men who acted aggressively as more capable of making decisions easily than women acting in the same manner (see table XVI). Thirdly, men acting aggressively were seen as more comfortable with their aggressiveness than their female counterparts. (see table XVII). Lastly, women were described by all therapists as slightly more dependent than men acting aggressively (see table XVIII).

On the item pertaining to the client's comfort with his aggression in the aggressive vignette there was an interaction between the professional group and the sex of the stimulus (see table XIX). Social workers described both men and women as slightly more comfortable with their 
aggression than psychologists saw them. There was also an interaction effect between the sex of the respondent and the sex of the stimulus (see table XX). Male therapists described males as more comfortable with their aggression than females. Female therapists described males as slightly more comfortable with their aggression than females.

A significant difference between social workers and psychologists was discovered on the dependency scale (see table XXI). Psychologists described both their male and female clients as slightly more dependent than social workers described their clients. There was also an interaction effect on this item between the sex of the respondent and the sex of the stimulus (see table XXII). Female therapists described males as slightly more dependent than females when they both were acting aggressively. Male therapists described females as more dependent than males when they were both acting in an aggressive manner.

In summary, the aggressive vignette had a total of 18 items, of which 9 were significant at the .05 level.

Dependent Vignette

There were only five questions in the vignette depicting dependency that revealed significant differences in the data and three were on the adjective checklist. 
An interaction effect between the sex of the respondent and the sex of the stimulus was found on the scales which described how much a client hid his emotions from others (see table $\mathrm{Xxx}$ ) and how aware he was of the feelings of others (see table XXXI). Male therapists described men acting dependently as hiding their feelings more than women acting dependently. Female therapists described women acting dependently as hiding their feelings slightly more often than men. In addition, male therapists described men acting dependently as less aware of the feelings of others than women. Female therapists saw women acting dependently as slightly less aware of the feelings of other than men.

On the active-passive scale a significant difference was found between male and female stimulus (see table XXXII). Therapists described men acting dependently as slightly more passive than women acting dependently.

\section{Fourth Hypothesis}

The fourth hypothesis posited that clinicians would have different feelings towards men and women who were behaving in an aggressive, assertive, or dependent manner. More specifically, the last three items following each vignette were designed to test this hypothesis. The clinician was asked, "How likely is it that you would 1) choose this person as a client 2) find yourself irri- 
irritated with this person, and 3) find it difficult to respond to this person". This hypothesis had three items out of nine which reached the .05 level of significance. Each vignette had one significant item. A discussion of the significant items follows.

\section{Self-Assertive Vignette}

In the self-assertive vignette a significant difference was found between the way that social workers and psychologists responded to the question, "How difficult would it be for you to respond to this person?" (see table XXXIV) Social workers saw working with self-assertive behavior as slightly less difficult than psychologists saw it.

Aggressive Vignette

There was an interaction effect between the sex of the respondent and sex of the formention regarding the therapist's emotional reaction to the aggressive client (see table XXXIII). Female therapists reported that they would be slightly more annoyed with males who acted in an aggressive manner than they were with females who acted similarly.: Male therapists were slightly more annoyed with females who acted aggressively than they were with males. 


\section{Dependent Vignette}

In the dependenct vignette there was a three way interaction between the group, sex of respondent, and sex of stimulus, on item three the question regarding how annoyed a clinician would be with a client.

\section{Fifth Hypothesis}

The last hypothesis stated that clinicians would see aggressive women and dependent men as more emotionally disturbed and in need of longer and more intensive treatment than dependent women and aggressive mem Item one in the last section following each vignette simply asked, "How serious a problem do you consider this person to have?" This item generated no significant differences or interaction effects on any of the vignettes. 
TABLE III

VARIABLE 17

DIFFERENCE BETWEEN MALE AND

FEMALE THERAPISTS

\begin{tabular}{|c|c|c|c|}
\hline & MACE & THERAPISTS & FEMALE \\
\hline PMF & 3.33 & PFF & 3.25 \\
\hline PMM & 2.25 & PFM & 4.25 \\
\hline SMM & 2.00 & SFF & 1.66 \\
\hline SMF & 2.00 & SFM & 2.25 \\
\hline MEAN & 2.74 & MEAN & 2.85 \\
\hline
\end{tabular}

TABLE IV

VARIABLE 21

INTERACTION BETWEEN SEX

OF RESPONDENT AND

SEX OF STIMULUS

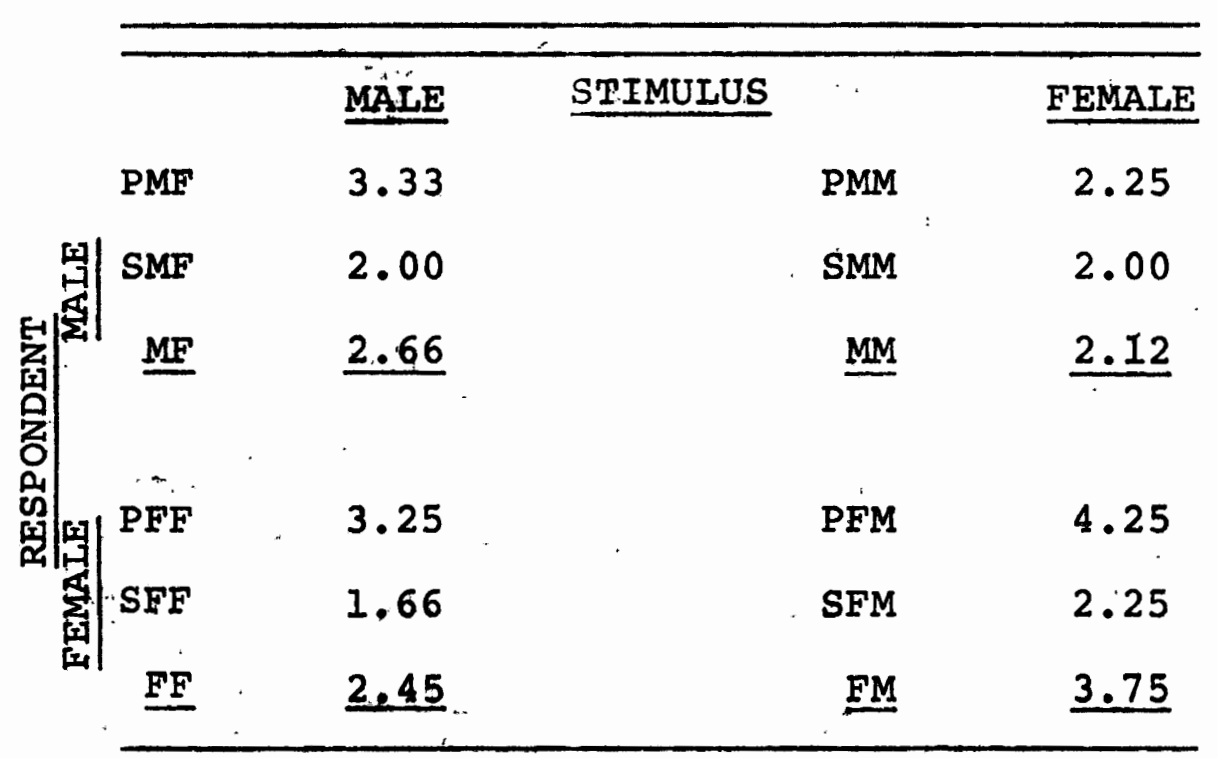


TABLE V

VARIABLE 17

DIFFERENCE BETWEEN MALE AND

FEMALE THERAPISTS

\begin{tabular}{lccc}
\hline & $\frac{\text { MALE }}{\text { THERAPISTS }}$ & $\frac{\text { FEMALE }}{2.25}$ \\
PMF & 2.66 & PFF & 2.25 \\
PMM & 1.75 & PFM & 3.50 \\
SMM & 1.75 & SFF & 2.33 \\
SMF & 2.50 & SFM & 3.25 \\
& & & \\
MEAN & 2.14 & MEAN & 2.83 \\
\hline
\end{tabular}

\section{TABLE VI \\ VARIABLE 20}

INTERACTION BETWEEN GROUP

AND SEX OF STIMULUS

\begin{tabular}{|c|c|c|c|c|}
\hline & & FEMALE & STIMULUS & MALE \\
\hline 我 & PMF & 2.66 & PMM & 1.75 \\
\hline 齐 & PFF & 2.55 & PFM & 3.50 \\
\hline E-1 & $\underline{P F}$ & 2.60 & $\underline{P M}$ & 2.62 \\
\hline 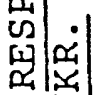 & SMF & 2.50 & SFM & 3.25 \\
\hline 3 & SFF & 2.33 & SMM & 1.75 \\
\hline $\begin{array}{l}\text { O } \\
\text { on }\end{array}$ & SF & 4.83 & SM & 5.00 \\
\hline
\end{tabular}


TABLE VII

VARIABLE 21

INTERACTION BETWEEN SEX OF RESPONDENT AND SEX OF STIMUItSS

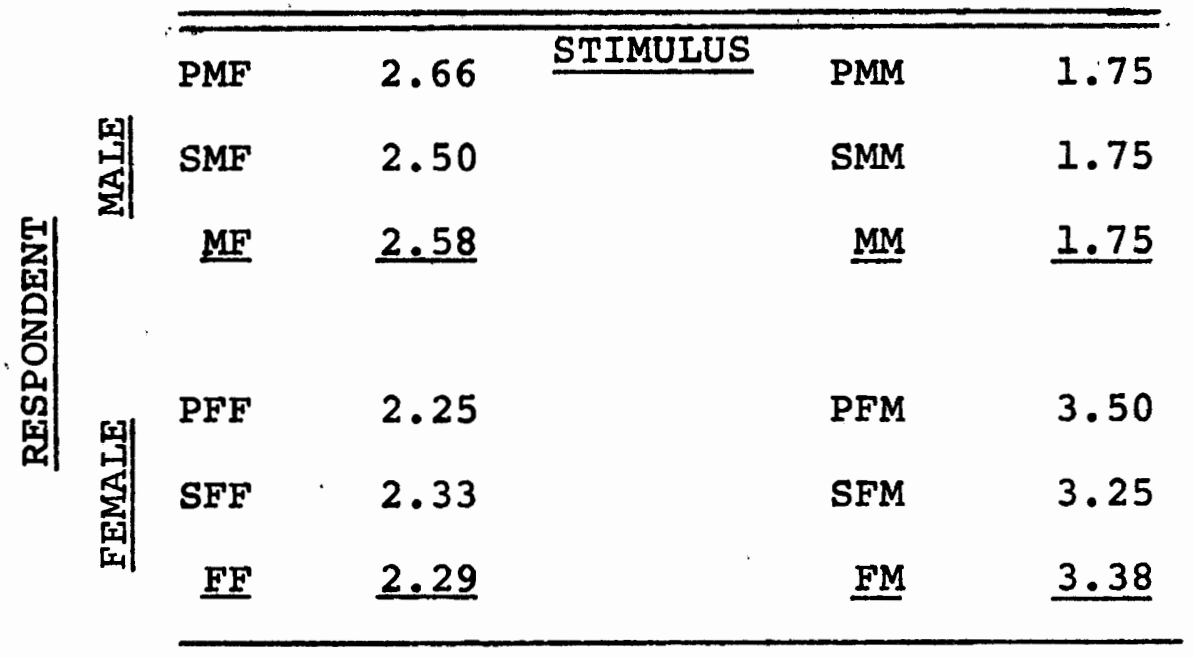




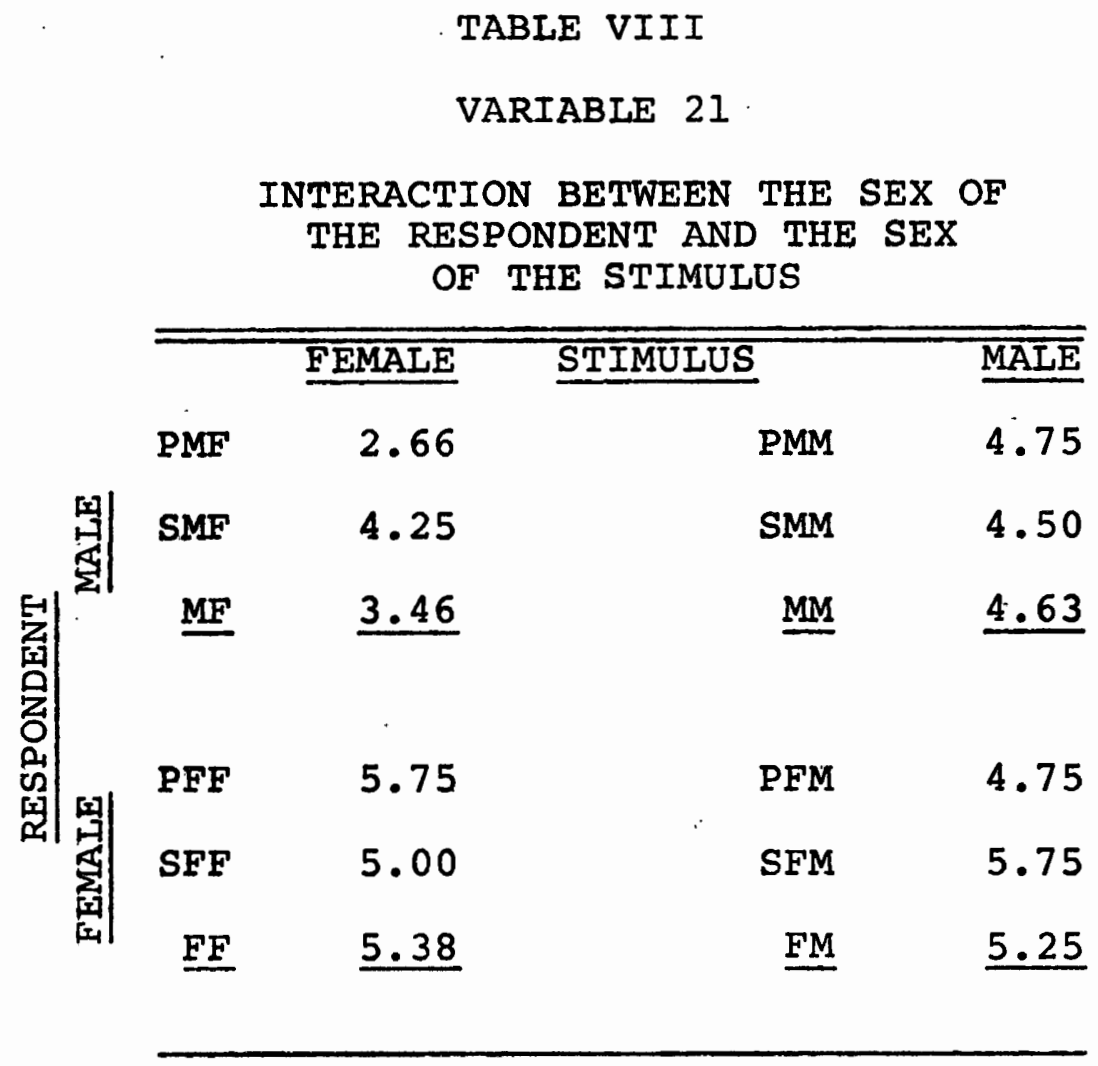


TABLE IX

VARIABLE 17

DIFFERENCE BETWEEN MALE AND

FEMALE THERAPISTS

\begin{tabular}{lllr}
\hline & MALE & THERAPISTS & FEMALE \\
\cline { 2 - 3 } PMF & 1.66 & PFF & 3.00 \\
PMM & 5.00 & PFM & 2.75 \\
SMM & 4.00 & SFF & 4.00 \\
SMF & 3.50 & SFM & 4.25 \\
& & & \\
MEAN & 3.54 & MEAN & 3.50 \\
\hline
\end{tabular}

TABLE $X$

VARIABLE 18

DIFFERENCE BETWEEN MALE AND

FEMALE. STTMUULU.S

\begin{tabular}{llllr}
\hline & MALE & STIMUIUS & & FEMALE \\
PMM & 5.00 & PMF & 1.66 \\
PFM & 2.75 & PFF & 3.00 \\
SFM & 4.25 & SFF & 4.00 \\
SMM & 4.00 & SMF & 3.50 \\
& & & \\
MEAN & 4.00 & MEAN & 3.04 \\
\hline
\end{tabular}


TABIE XI

VARIABLE 21

INTERACTION BETWEEN SEX OF RESPONDENT AND SEX OF STIMULUS

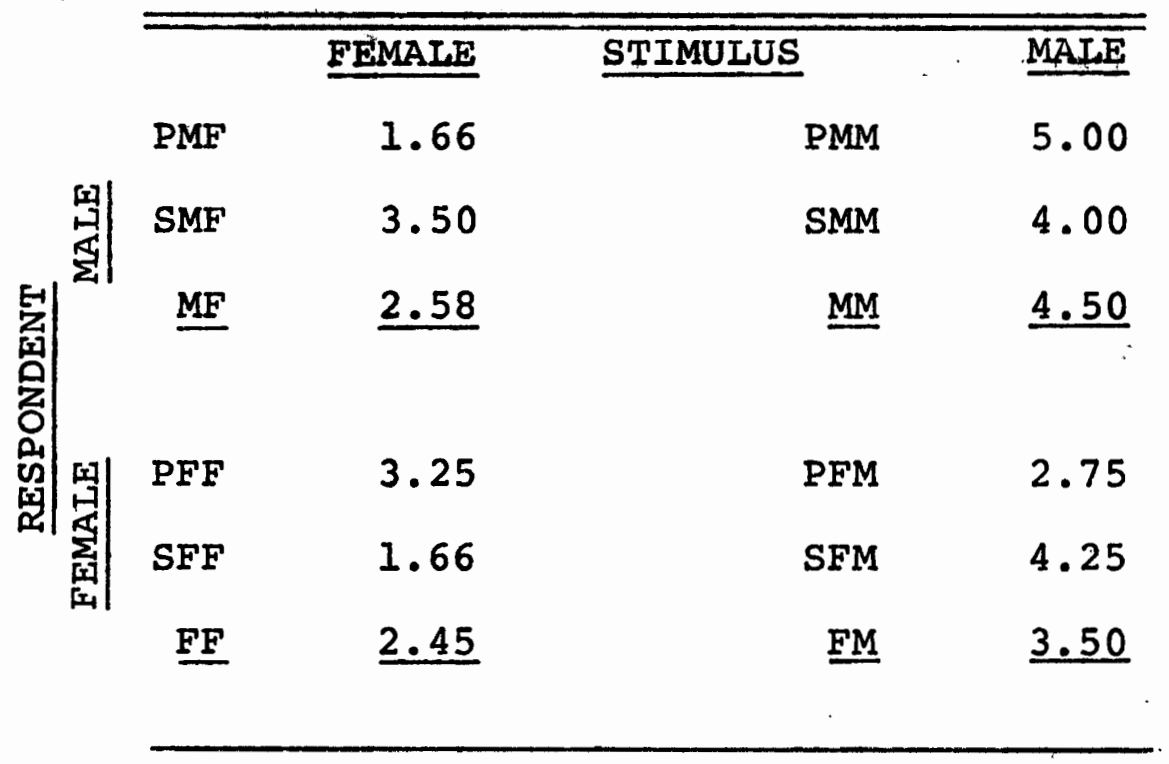


TABLE XII

VARIABLE 18

DIFFERENCE BETWEEN MALE AND

FEMALE STIMULUS

\begin{tabular}{|c|c|c|c|c|}
\hline & MALE & STIMULUS & & FEMALE \\
\hline PMM & 2.75 & & PMF & 1.33 \\
\hline PFM & 2.30 & & PFF & 1.75 \\
\hline SFM & 2.00 & & SFF & 2.00 \\
\hline SMM & 2.25 & & SMF & 3.00 \\
\hline MEAN & 2.32 & & MEAN & 2.02 \\
\hline
\end{tabular}

TABLE XIII

VARIABLE 18

DIFFERENCE BETWEEN MALE AND

FEMALE STIMULUS

\begin{tabular}{|c|c|c|c|c|}
\hline & MALE & STIMULUS & & FEMALE \\
\hline PMM & 4.50 & & PMF & 2.00 \\
\hline PFM & $4.7,5$ & & PFF & 4.30 \\
\hline SFM & 5.00 & & SFF & 4.00 \\
\hline SMM & 4.00 & & SMF & 4.00 \\
\hline MEAN & 4.50 & & MEAN & 3.57 \\
\hline
\end{tabular}




\section{TABLE XIV}

VARIABLE 21

INTERACTION BETWEEN SEX

OF RESPONDENT AND

SEX OF STIMUIUS

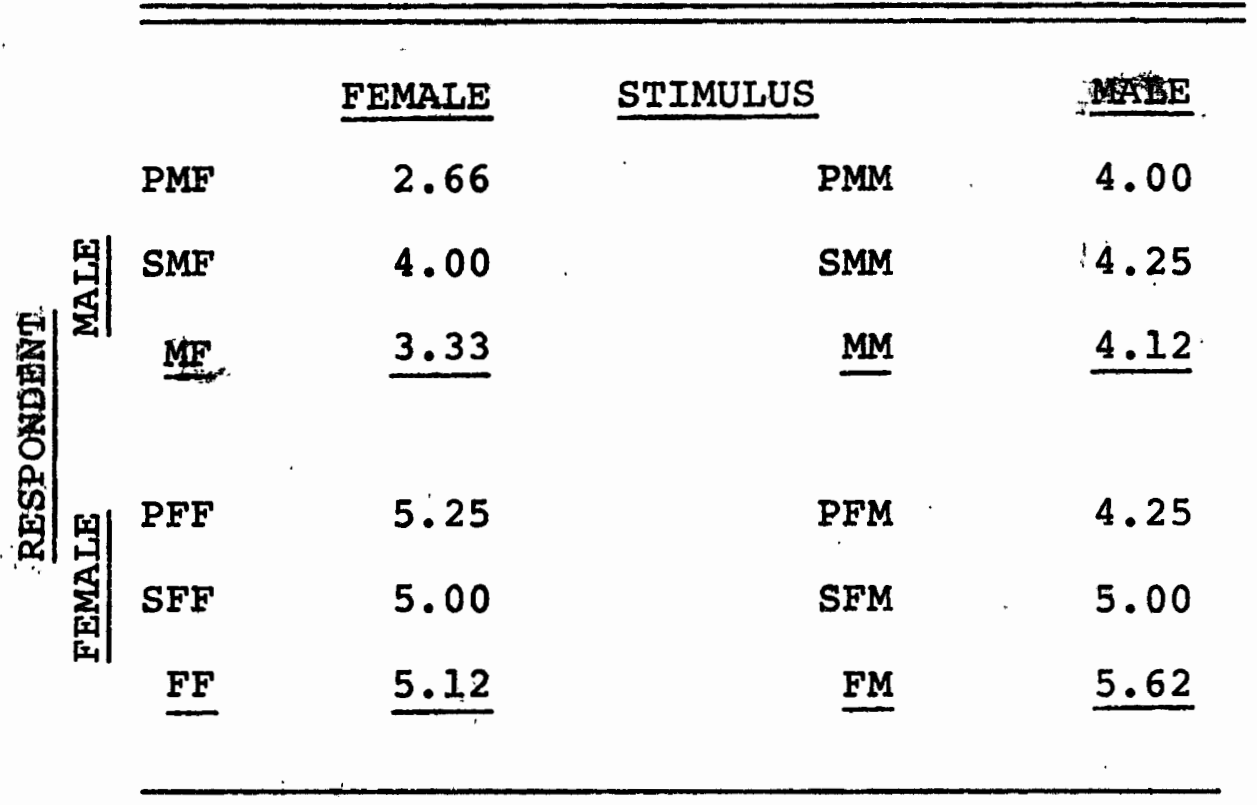


TABLE XV

VARIABIE 18

DIFFERENCE BETWEEN MALE AND

FEMALE STIMULUS

\begin{tabular}{llll}
\hline & MALE & STIMULUS & FEMALE \\
PMM & 4.50 & PMF & 2.00 \\
PFM & 5.75 & PFF & 5.25 \\
SFM & 5.75 & SFF & 5.33 \\
SMM & 4.00 & SMF & 4.75 \\
& & & MEAN \\
\hline
\end{tabular}

TABIE XVI

VARIABLE 18

DIFFERENCE BETWEEN MALE AND

FEMALE STIMUIUS

\begin{tabular}{lccc}
\hline & MALE & STIMULUS & FEMALE \\
PMM & 4.25 & PMF & 1.33 \\
PFM & 3.75 & PFF & 2.30 \\
SFM & 4.25 & SFF & 3.66 \\
SMM & 3.75 & SMF & 3.25 \\
& & & \\
MEAN & 4.00 & MEAN & 2.63 \\
\hline
\end{tabular}


TABLE XVII

VARIABIE 18

DIFFERENCE BETWEEN MALE AND

FEMALE STIMULUS

\begin{tabular}{|c|c|c|c|}
\hline & MAIE & STIMULUS & FEMALE \\
\hline PMM & 5.00 & PMF & 3.00 \\
\hline PFM & 5.00 & PFF & 5.00 \\
\hline SFM & 5.50 & SFF & 4.66 \\
\hline SMM & 4.75 & SMF & 4.25 \\
\hline MEAN & 5.06 & MEAN & 4.25 \\
\hline
\end{tabular}

TABLE XVIII

VARIABLE 18

DIFFERENCE BETWEEN MALE AND

FEMALE STIMUIUS

\begin{tabular}{llll}
\hline & MALE & STIMULUS & FEMALE \\
PMM & 4.25 & PMF & 2.33 \\
PFM & 3.50 & PFF & 5.75 \\
SFM & 5.00 & SFF & 4.33 \\
SMM & 4.00 & SMF & 3.25 \\
MEAN & 4.18 & & MEAN \\
\hline
\end{tabular}


TABLE XIX

VARIABLE 20

INTERACTION BETWEEN GROUP AND SEX OF STIMULUS

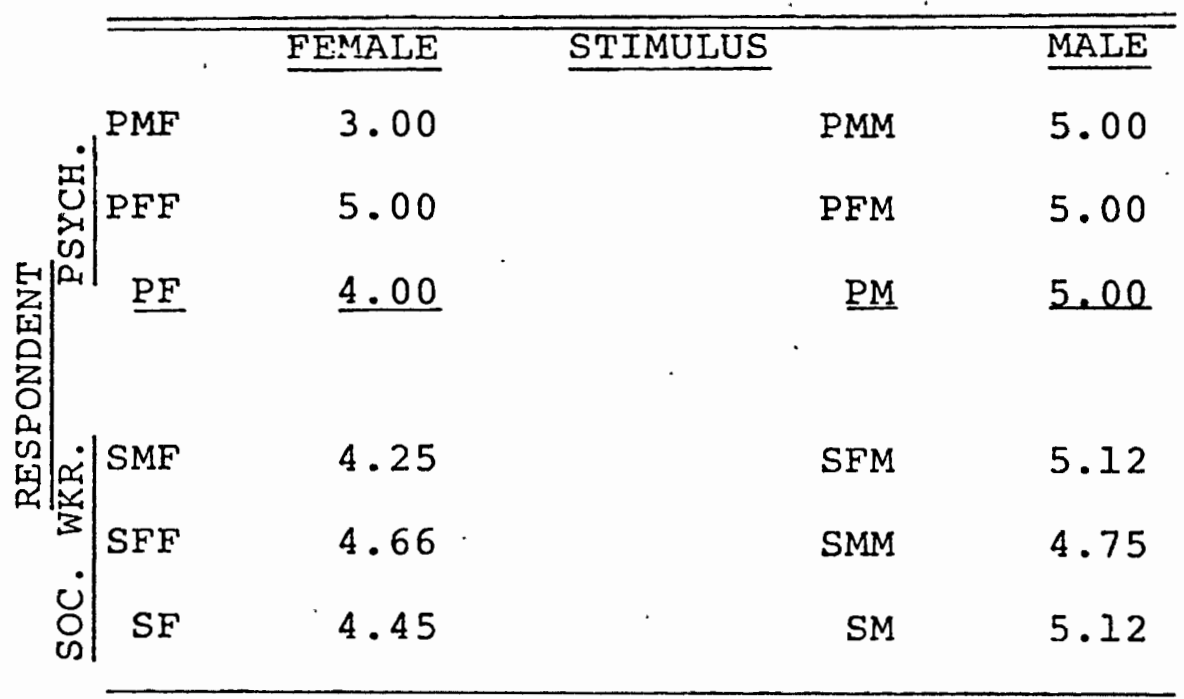

TABLE XX

VARIABLE 21

INTERACTION BETWEEN SEX OF RESPONDENT AND SEX OF STIMULUS

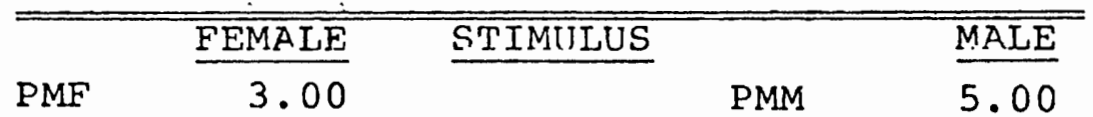

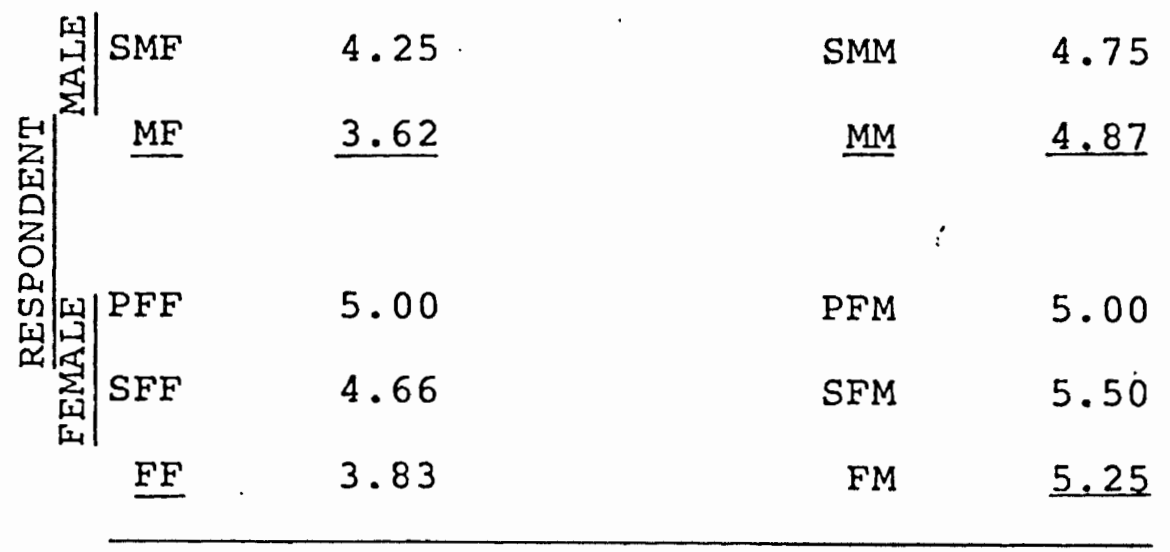


TABLE XXI

VARIABLE 16

BIFFERENCE BETWEEN SOCIAI WORKERS

AND PSYCHOLOGISTS

SOCIAL

WORKER

GROUP

PSY̌CHOLOGISTS

SFF

4.33

PMF

2.33

SFM

5.00

PMM

4.25

SMM

4.00

PFF

5.75

SMF

3.25

PFM

3.50

MEAN

4.14

MEAN

3.95

TABLE XXII

VARIABLE 21

INTERACTION BETWEEN SEX OF RESPONDENT AND SEX OF STTMULUS.

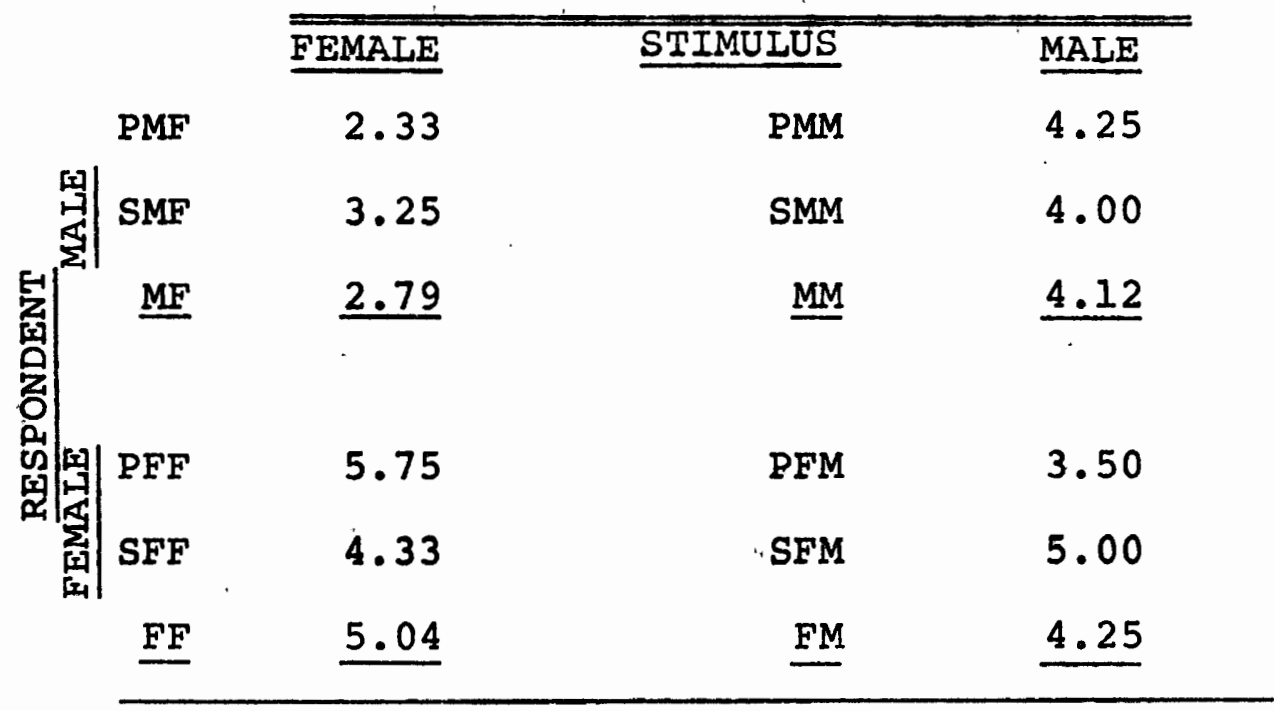


TABLE XXIII

VARIABLE 18

DIFFERENCE BETWEEN MALE AND

FEMALE STEUTLOTS

\begin{tabular}{lllll}
\hline & MALE & STIMULUS & & FEMALE \\
\hline PMM & 4.50 & PMF & 1.33 \\
PFM & 3.75 & PFF & 3.75 \\
SFM & 4.25 & SFF & 3.66 \\
SMM & 3.75 & SMF & 4.00 \\
& 4.06 & & MEAN & 3.18 \\
\hline
\end{tabular}

TABLE XXIV

VARIABLE 2.1

INTERACTION BETWEEN SEX OF RESPONDENT AND SEX OF STIMULITS

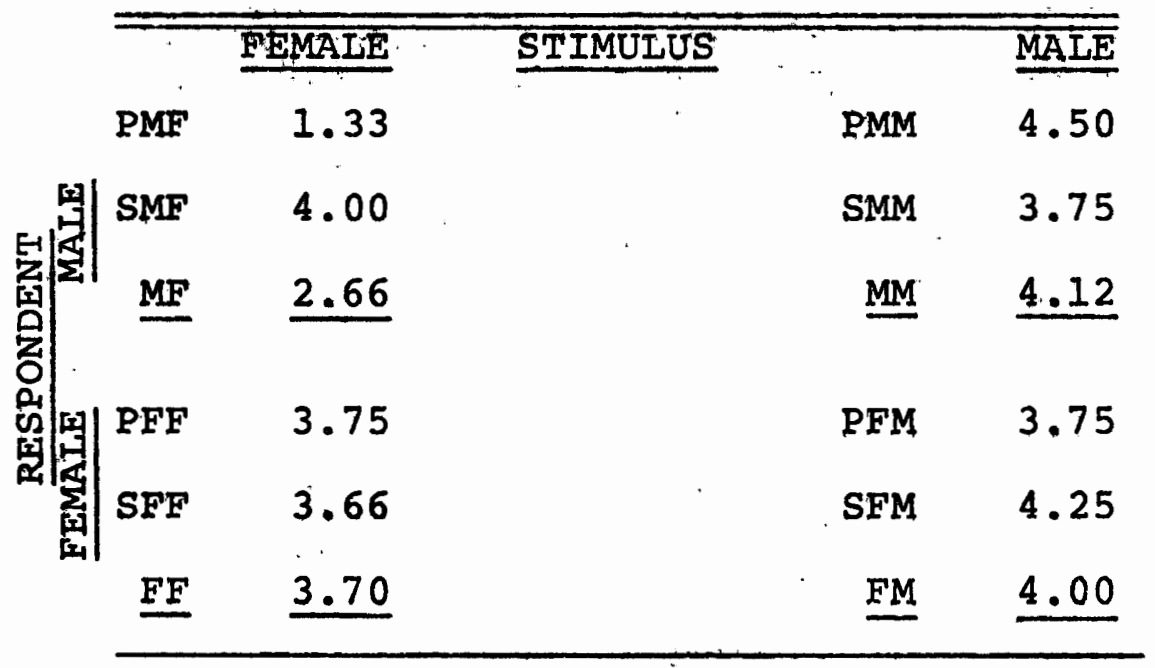


TABLE XXV

VARIABLE 18

DIFEERENCE BETWEEN MALE AND

FEMALE STIMULUUS

\begin{tabular}{llll}
\hline \hline & MALE & STIMULUS & \\
PMM & 5.00 & PMF & 2.66 \\
PFM & 3.25 & PFF & 4.75 \\
SFM & 4.25 & SFF & 3.33 \\
SMM & 4.25 & SMF & 4.25 \\
MEAN & 4.18 & MEAN & 3.74 \\
\hline
\end{tabular}

TABLE XXVI

VARIABLE 21

INTERACTION BETWEEN SEX OF RESPONDENT AND SEX, OF STIMULUS

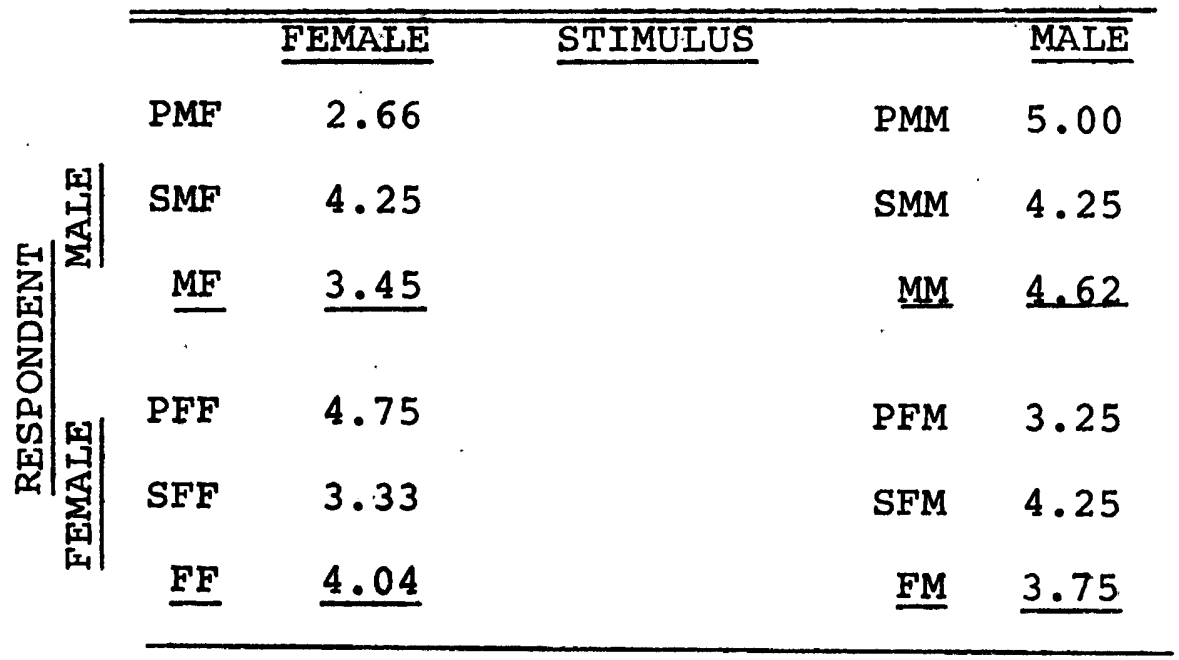


TABLE XXVII

VARIABIE 21

INTERACTION BETWEEN SEX OF RESPONDENT

AND SEX OF STIMULUS

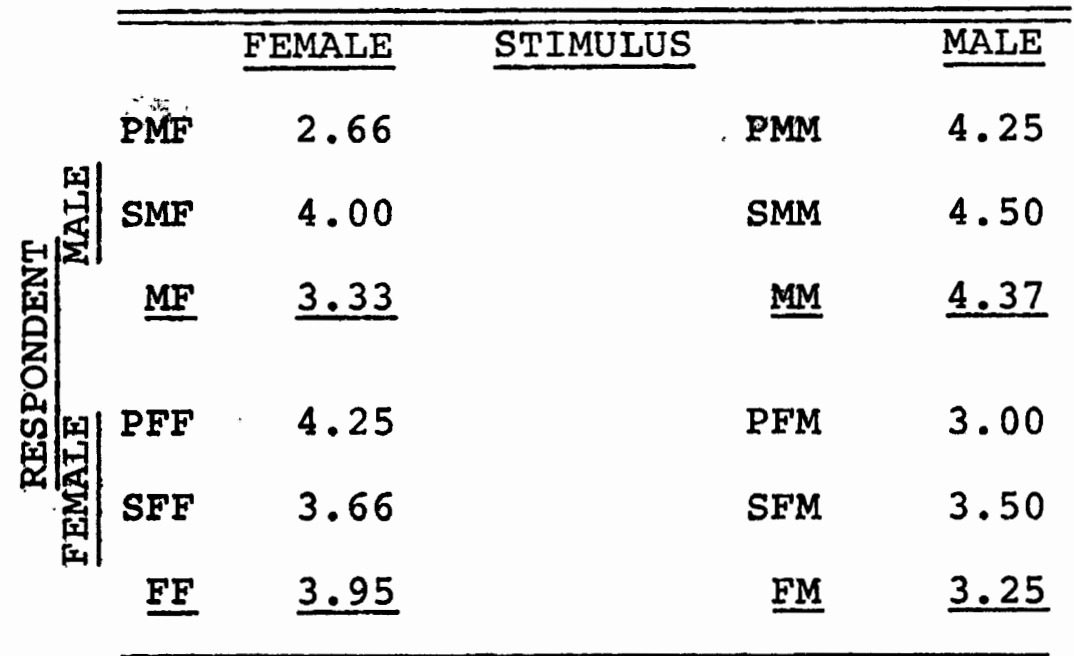


TABLE XXVIII

VARIABLE 18

DIFFERENCE BETWEEN MALE AND

FEMALE STIMULTS

\begin{tabular}{lllll}
\hline & MALE & STIMULUS & & $\frac{\text { FEMALE }}{2}$ \\
\cline { 2 - 3 } PMM & 4.25 & PMF & 1.33 \\
PFM & 3.50 & PFF & 4.50 \\
SFM & 3.25 & SFF & 3.33 \\
SMM & 2.50 & SMF & 4.00 \\
& & & MEAN & 3.34 \\
\hline
\end{tabular}

TABLE XXIX

VARIABLE 21

INTERACTION BETWEEN SEX OF RESPONDENT AND SEX OF STIMUIUTS.

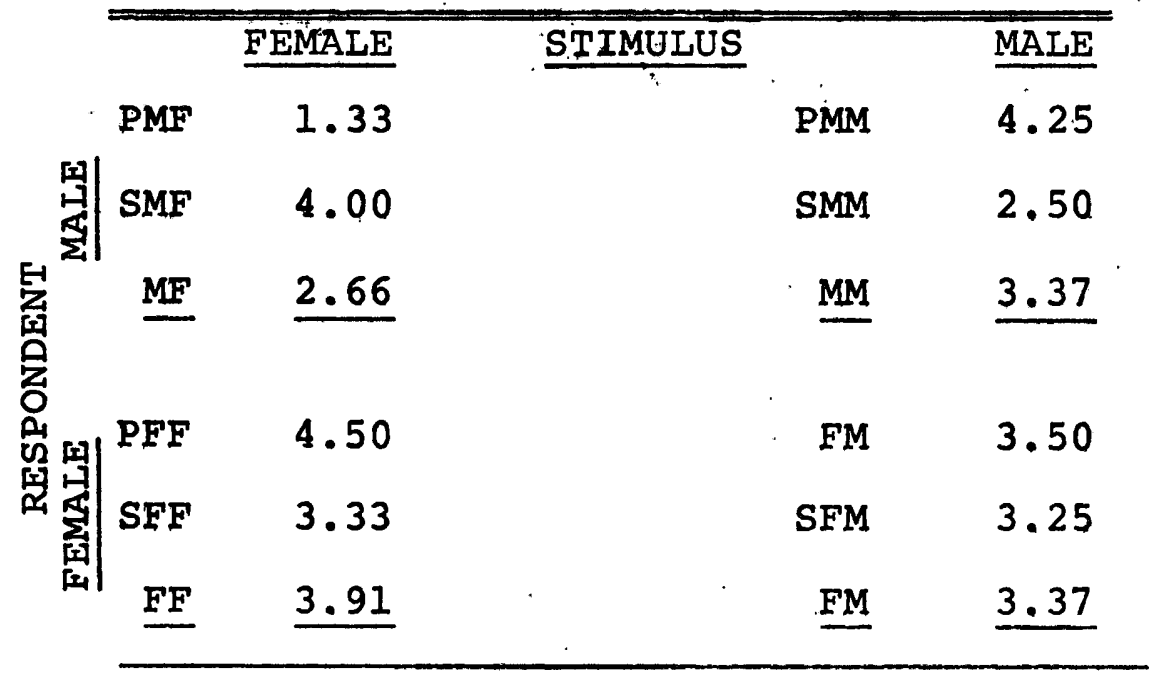


TABLE XXX

VARIABLE 21

INTERACTION BETWEEN SEX OF RESPONDENT AND SEX OF STIMULUS.

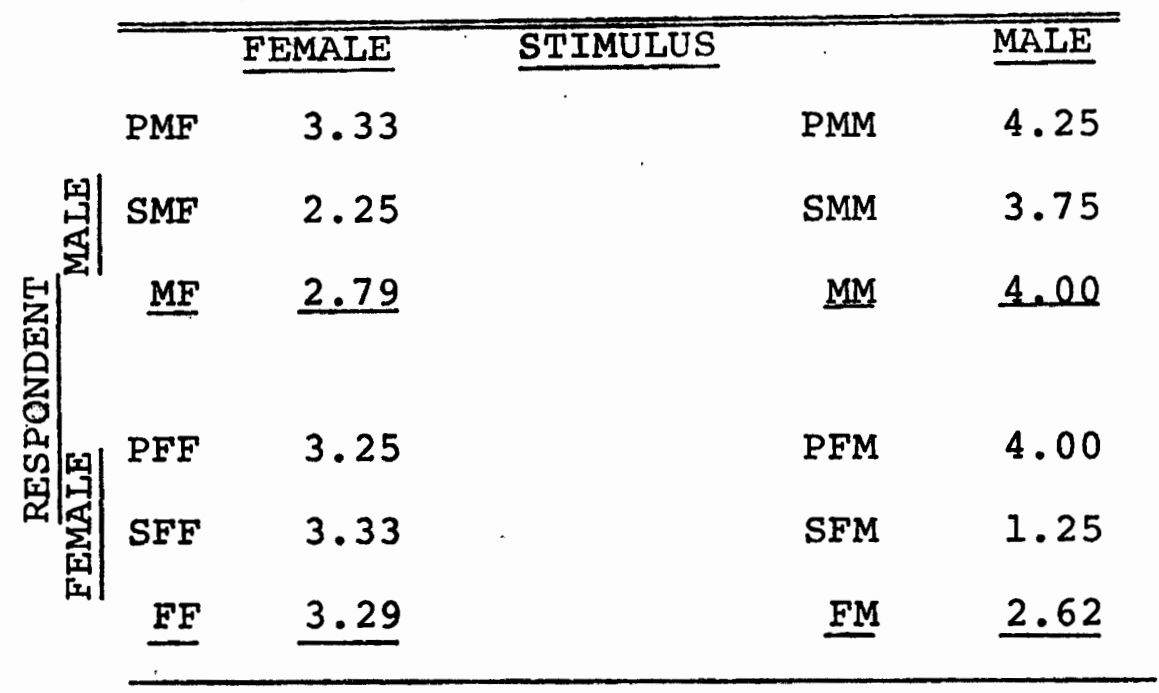

TABLE XXXI

VARIABLE 21

INTERACTION BETWEEN SEX OF RESPONDENT

AND SEX OF STIMULUS

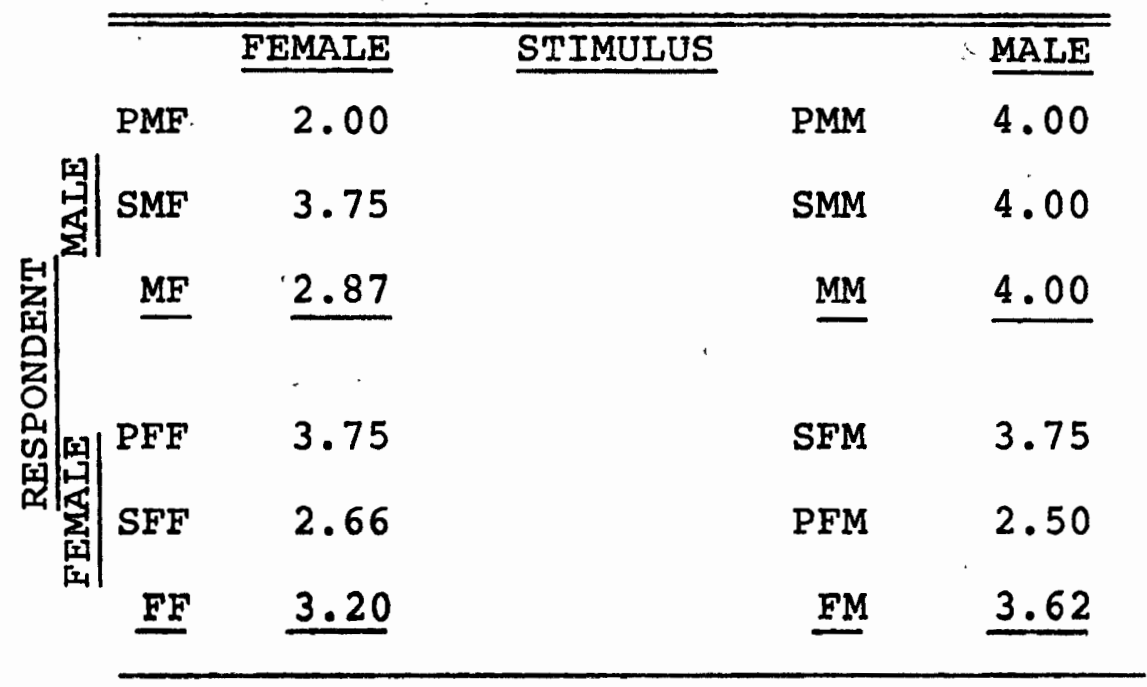


TABLE XXXII

VARIABLE 18

DIFFERENCE BETWEEN MALE AND

FEMALE STIMULUS

\begin{tabular}{llll}
\hline & MALE & STIMULUS & FEMALE \\
PMM & 4.75 & PMF & 3.33 \\
PFM & 3.25 & PFF & 5.25 \\
SFM & 4.25 & SFE & 5.00 \\
SMM & 3.75 & SMF & 4.00 \\
MEAN & 4.00 & & \\
\hline
\end{tabular}


TABLE XXXIII

VARIABIE 21

INTERACTION BETWEEN SEX OF RESPONDENT AND SEX OF STIMULUS

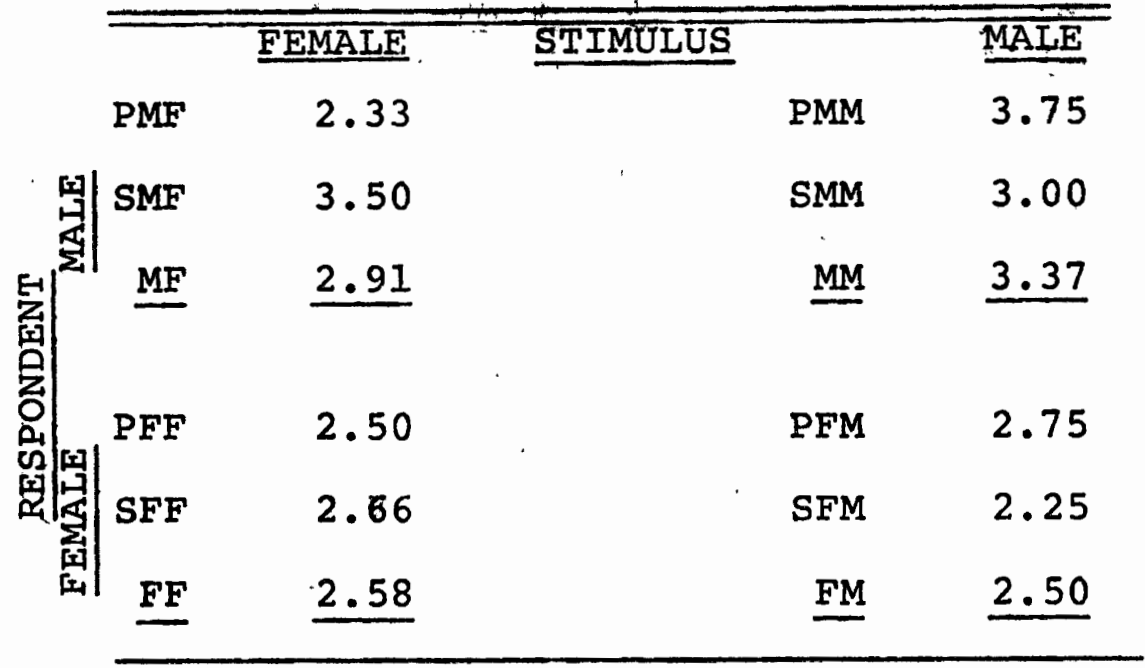

TABLE XXXIV

VARIABLE 16

DIFFERENCE BETWEEN SOCIAL WORKERS AND PSYCHOLOGISTS

\begin{tabular}{llllc}
\hline \hline & $\begin{array}{c}\text { SOCIAI } \\
\text { WORKER }\end{array}$ & & GROUP & PSYCHOLOGISTS \\
SFF & 4.33 & & PMF & 4.33 \\
SFM & 4.25 & & PMM & 3.25 \\
SMM & 4.50 & & PFF & 4.25 \\
SMF & 4.50 & PFM & 4.25 \\
& & & MEAN & 4.02 \\
\hline
\end{tabular}


CHAPTER VII

\section{SUMMARY}

In summary, all the hypotheses had several items which were significant at the .05 level except for one hypothesis. This hypothesis stated that clinicians would see agressive women and dependent men as more emotionally disturbed and in need of longer treatment. Essentially, clinicians described aggressive, selfassertive, and dependent behavior differently depending upon whether it was performed by a man or a woman. The significant items on the adjective ckecklist suggested that clinicians tend to perceive their clients in a stereotyped manner. While the results were not as conclusive, they also had different responses to and different feelings about a client's behavior depending upon the sex of the client. Clinicians did not appear to have different treatment goals or different diagnostic ratings for these same clients. The trends in the data will now be discussed, first looking at the three vignettes, followed by the five measures, and finally, the seven variables or tests. First, the results by vignette will be summarized. The vignette portraying aggressiveness contained eleven significant items. Seven items were significant 
on the self-assertive. vignette. The dependent vignette had five significant items. In summary, aggressive behavior had more of a tendency to elicit different responses from clinicians than self-assertive or dependent behavior.

of the five measures (the items in the questionnaire designed to test the five hypotheses) one measure, the adjective checklist, revealed many more significant differences than the other four measures. The adjective checklist on the aggressive vignette contained nine significant items, while the self-assertive vignette contained four and the dependent vignette contained three. In comparison the response categories contained one significant item in each of the vignettes. The measure on goals of treatment contained one significant difference on the self-assertive vignette. The fourth measure, which determined how the clinician felt about the client, had one significant item on each vignette. The fifth measure, which asked how serious a problem the client had, contained no significant items. In summary, the adjective checklist was probably the most reliable measure of counselor bias, due to the fact that it simply measured how a counselor perceived a specific behavior. The response categories and the goal measures were extremely difficult to interpret, because the counselor's response could be due to theoretical 
orientation or due to other attributes and, therefore, might not necessarily imply counselor bias.

Out of the seven factors studied, there were only two which were significant at the .05 level on several items. There were interaction effects between the sex of the respondent and the sex of the stimulus on fourteen items. There were significant differences between male and female stimulus on eleven items. Each of the remaining five variables showed significance on only two or three different items each. For example, whether a clinician is a social worker or a psychologist did not account for the difference in responses to the vignette. One of the more interesting findings with this variable, however, was that social workers reported that they had found it easier to work with selfassertive behavior. 
CHAPTER VIII

\section{DISCUSSION}

Trends in the Data

First, same sex alinical bias will be discussed. Second, the positive and negative aspects of the instrument used in this study will be delineated.

It is interesting to note that clinicians may in some ways be more biased negatively towards their own sex. For example, female therapists described aggressive female clients as more aggressive than male clients, while male therapists saw aggressive female clients as less aggressive than male clients. At the same time female therapists were less annoyed by aggressiveness in females. A second example is that female therapists described women acting self-assertively as less aware of the feelings of others than were their self-assertive male counterparts. A third example, is that male therapists described men acting dependently as less aware of the feelings of others than women. The instrument utilized in this study was a very complex one for two reasons. The first reason for this complexity was that this researcher was attempting to measure clinicians' responses to, goals for, feelings about, and judgements on specific client behaviors. 
In addition, clinicians' descriptions of these specific behaviors were compared to their hypothetical responses.

The second reason for the complexity of the instrument was that for every hypothesis except the one which measured clinician judgement, each measure had several items to test each hypothesis. If there had been one item only for each hypothesis the task of interpreting the results would have been simplified. However, the advantage to having several items for each hypothesis was that it greatly enhanced the reliability of the data obtained from each measure. Since there were no two items on the same vignette which were significant in exactly the same manner the items appeared to be independent of one another.

In summary, the clearest trend was for clinicians to describe men and women engaging in self-assertive, aggressive and dependent behavior in a stereotyped manner. They also appeared to have significantly different feelings about the clients portrayed in the vignettes. These biases were not as strong, however, in the response or goal sections of the instrument. This trend in the data leads this researcher to speculate that even though clinicians reveal their biases by perceiving differently and feeling differently about the exact same behaviors in men and women, they do not necessarily translate these biases into prejudicial behavior in the actual counseling interview. 
A study similar to this one using undergraduate students as subjects might reveal whether or not advanced training is responsible for reducing clinicians' biased attitudes. Only a thorough process study could determine whether or not clinicians, in fact, would behave in a biased manner during the counseling session.

Implications for Counselor Training Programs

One of the reasons this study was undertaken was to make recommendations for improvements in counselor training programs. Hopefully, such an effort would enable practitioners to better deal with the problems of contemporary women.

Swartz (1974) documented and discussed her findings that the social work profession has consistently underestimated the role which the sex of the client and worker plays in therapy. This has often resulted in ineffective interventions. She maintained that the role of sex has not been explored to the extent that race, class, and ethnicity have. In that specialized sex-role pressures do exist, Swartz felt that it was important for the social worker to understand that in the construction of new roles, workers and clients have to deal with the available male and female support systems as well as the sexual stereotypes of the culture. 
Even though in 1978 there are many more studies on the biasing effects of client and clinicician sexroles in psychotherapy, and even though many more people have been to workshops designed to increase awareness of possible biases, this researcher recommends that these workshops continue, but with a more behavioral focus. A study by Gun (1975) indicated that irrespective of descriptive variables, such as race and class, or the level of initial awareness of sex-role stereotypes, that education students' attitudes towards women's roles and rights in contemporary society became significantly more liberal as a result of a workshop on the subject. The results of this study implied that clinicians were sometimes more biased towards their own sex. This bias would indicate that perhaps consciousness raising programs are still needed. These programs should focus on helping counselors look at their responses to clients of their own sex for possible biases as well as clients of the opposite sex. Specifically, the areas of potential importance for counselor training include increasing their awareness as to how their attitudes are translated into prejudicial behavior towards clients and include learning how to be more reinforcing of beneficial astereotypic client statements or behavior. 
Directions for Further Research

Two directions for further research should be considered. The first direction involves the modification of the questionnaire utilized in this study, increasing the sample size, and expanding the geographical area from which the sample was drawn. The second involves changing the study in the direction of a process study. This would permit studying how a counselor actually behaves in the couseling interview rather than how he says he behaves.

In retrospect, the adjective checklist appeared to give the most specific and comprehensible data. The items, regarding how a therapist would respond in a hypothetical clinical situation and regarding the treatment goals he would have used were too difficult to interpret. This difficulty resulted from the fact that theoretical orientation and other factors could have accounted for the variation in responses. Further studies should attempt to assess the relationship between a clinician's responses to the adjective checklist and his actual behavior in a clinical interview. In addition, the intercorrelations among items could be studied in order to determine whether different items were measuring the same phemomenon. One of the merits of this study was that practising clinicians were used as subjects rather 
than counseling graduate students. However, in order to guarantee the generalizability of the data, future studies should retest the hypotheses with larger sample spaces and with a more geographically varied population.

Had this study been designed as more of a process study, more information about actual clinical behavior might have been obtained. For example, confederates could have memorized aggressive, assertive, or dependent scripts and then have presented themselves as clients to the clinician sample. The clinical interview could be videotaped and then rated by a group of trained judges for biased behavior. In addition, the clinician would be asked to fill out the questionnaire designed for this study. In this ay, the relationship between a clinician's attitudes and his behavior in the actual counseling situation, could be studied in much greater detail.

To conclude, the major recommendation of this researcher is that both male and female clinicians should examine their own behavior and attitudes with the goal of reducing their own biases. They can then effectively facilitate the growth and füll potential of each individual client. 


\section{A LIST OF WORKS CONSULTED}

\section{BOOKS}

Chesler, P. Women and Madness. Garden City, New Jersey: Doubleday, 1972 .

Fabrikant, Benjamin. "The Psychotherapist and the Female Patient" in V. Franks \& V. Burtle, eds. Women in Therapy. New York: Brunner/Mazel, 1974.

Franks, Violet, and Burtle, Vasonti. Women in Therapy: New Psychotherapies for a Changing Society. New York: Brunner/Mazel, 1974.

Kiesler, Donald. The Process of Psychotherapy, Empirical Foundations and Systems of Analysis. Chicago: Aldine Publishing Co., 1973.

Szasz, T. S. The Manufacture of Madness: A Comparative study of the Inquisition and the Mental Health Movement. New York: Harper, 1970.

Szasz, T.S. The Myth of Mental Illness: Foundations of a Theory of Human Conduct. New York: HoeberHarper, 1961.

Szasz, T. S. Psychiatric Justice. New York: MacMillan1965.

\section{JOURNALS}

Abernathy, Virginia. "Cultural Perspectives on the Impact of Women's Changing Roles on Psychiatry." American Journal of Psychiatry $133(6)$ (June 1976): 657-661.

Abramowitz, Stephen I., and Abramowitz, Christine V. "Should Prospective Women Clients seek Out Women Practitioners?" Proceedings of the 81st Annual Convention of the APA 8 (1973): 505-506.

Abramowitz, Stephen I.; Abramowitz, Christine V.; Jackson, Carolyn; and Gomes, Beverly. "The Politics of Clinical Judgement; What Non-Liberal Examiners Infer About Women Who Do No Stifle Themselves." Journal of ronsulting and Clinical Psychologists 41(3) (December 1973): 385-391. 
Bem, S. L. "The Measurement of Psychological Androgony." Journal of Consulting and Clinical Psychology. 42(1974): 155-162.

Biller, Henry. "Sex Role Uncertainty and Psychopathology." Journal of Individual Psychopathology 29 (May 1973): 24-25.

Birk, Janice M. "Interest Inventories: A Mixed Blessing." Vocational Guidance Quarterly 22(4) (June 1974): 280-286.

Brody, J. P., and Detre, T. "Criteria Used by Clinicians in Referring Patients to Individual or Group Therapy." American Journal of Psychotherapy 26 (1972): $17 \overline{6-184}$.

Broverman, Inge, et. al., "Sex-Role Stereotypes: A Current Appraisal." Journal of Social Issues $28(2)$ ( $(972)$.

Chase, W. P. "Measurement of Attitudes Towards Counseling." Educational Psychology Measurement; 6 $(1946): 467-475$.

Chasen, Barbara, and Weinberg, Sharon I. "Diagnostic Sex-Role Bias: How Can We Measure It?" Journal of Personal Assessment 39 (December 1975): $620-629$.

Coie, J. D.; Pennington, B. F.; and Buckley, H. H. "Effects of Situational Stress and Sex-Roles on the Attribution of Psychological Disorder." Journal of consulting clinical Esychology 4 (1974): 559-568.

Collins, A. M.; and Sedlacek, W. E. "Counselor Ratings of Male and Female Clients." National Association for Women Deans, Administrators and Counselors 37 (Spring 1974): 128-132.

Costrich, Norma, et. al. "When Stereotypes Hurt: Three Studies of Penalties for Sex-Role Reversals:" Journal of Experimental Social Psychology 11(6) (November 1975): 520-550. 
Delk, J. L., and Ryan, T. "Sex-Role Stereotyping and A-B Therapist Status: Who is More Chauvinistic?" Journal of Consulting and Clinical Psychology 43 (1975): 589 .

Doherty, M. "Sexual Bias in Personality. Theory." Counseling Psychologists 4(1) (1973): 67-75.

Etzkowitz, Shari. "Sexism and Psychotherapy." Radical Therapist (April-May 1971): 2 .

Fuller, F. F. "Influence of sex of Counselor and of Client on Client Expression of Feeling." Journal of Counseling Psychology 10 (1963): $34-40$.

Goldberg, Phillip. "Are Woman Prejudiced Against Women." Transaction (April 1968): 28-30.

Goodall, R. "Garden Variety Sexism: Rampant Among Psychologists." Psychology Today 6(9) (1973): 9 .

Greenberg, Roger P. "Sexual Bias on Rorschach Administration." Journal of Personality Assessment 36 (August 1972): 336-339.

Gross, Herbert, et. al. "The Effect of Race and Sex on the Variation of Diagnosis and Disposition in a Psychiatric Emergency Room." The Journal of Nervous and Mental Disease CXIVIII. (June 1969).

Grossman, Susanne. "Sex Role Stereotypes as a Function of Counselor Judgements." Education, Guidance and Counseling (1976): $645 \overline{5 A}$.

Haan, N.., and Livson, N. "Sex Differences in the Eyes of Expert Personality Assessors: Blind Spots?" Journal of Personality Assessment 37 (1973): 486-492.

Heilbrun, A. B. "Toward Resolution of the DependencyPremature Termination Paradox for Females in Psychotherapy." Journal of Consulting and Clinical Psychology $34(5)$ (1970): $382-386$. 
JOURNALS

Hill, Clara E. "Sex of client and Sex and Experience Level of Counselor." Journal of Counseling psychology 22 (1) (January 1975): 6-11.

Hopke, William. "The Measurement of Counselor Attitudes." Journal of Counseling Psychology 2 (1955): 212-216.

Hurvith, N. "Psychotherapy as a Means of Social Control." Journal of Counseling and Clinical Psychology 40(2)(1973).

Lewittes, D. J.: Möselle; J.A. and. Simmons, W. L. "Sex-Role Bias in Clinical Judgements Based on Rorschach Interpretations." Proceedings of the 81st Annual Convention of the American psychological Association 8 (1973): 495-496.

McClain. "Is the Counselor a Woman?" Journal of Counseling Psychology 46 (5): (I968).

McKee, J. P., and Sherriffs, A. C. "The Differential Evaluation of Males and Females." Journal of Personality 25 (1957): 356-371.

Maslin, Audrey, and; Davis, Jerry L. "Sex-Role Stereotyping as a Factor in Mental Health Standards Among Counselors in Training." Journal of Counseling Psychology 22(2) (March 1975) 87-91.

Masling, J., and; Harris, S. "Sexual Aspects of TAT Administration." Journal of Consulting and Clinical Psychology 33 (1969): 166-169.

Miller, D. "The Influence of the Patients Sex on Clinical Judgement." Smith College Studies in Social Work 44 (February 1974): 89-100.

Millman, Marcia. "Observations on Sex-Role Research." Journal of Marriage and Family 33 (November 1971): 772-776.

Mischel, Harriet N. "Sex Bias in the Evaluation of Professional Achievements." Journal of Educational Psychology 66 (April 1974): 157-166. 
JOURNALS

Mischel, Harriet N. "Sex Bias in the Evaluation of Professional Achievements." Journal of Educational Psychology 66 (April 1974): 157-166.

Nowacki, C. M., and Poe, C. A. "The Concept of Mental Health as Related to the Sex of the Person Perceived." Journal of Consulting and Clinical Psychology 40 (1973): 160 .

Oleski, Wendy; and Balten, Lawrence. "Sex and Empathy." Journal of Counseling Psychology 19 (November 1972): 559-562.

Parker, G. V. "Some Concomitants of Therapist Dominance in the Psychotherapy Interview." Journal of Consulting Psychology 31 (1967): 313-318.

Porter, E. H., Jr. "The Development and Evaluation of a Measure of Counseling Interview Procedures. Part I. The Development?" Educ: Psych. Meast. (1943) : 105-125.

Rice, David. "Patient Sex Differences and Selection for Individual Psychotherapy." The Journal of Nervous and Mental Disease CXIVIII.

Rochester, Dean E. "Sex and Age as Factors Relating to Counselor Attitude Change." Counselor Education and Supervision 11 (March 1972): 214-218.

Rosenthal, D. "Changes in Some Moral Values Following Psychotherapy:" Journal of Consulting Psychology $19(1955): 431-4 \overline{36}$.

Shader, Richard; Benstock, William; Ohly, Jane; and Scott, Dorothy. "Biasing Factors in Diagnosis and Disposition." Comprehensive Psychiatry $X(I)$

Schlossberg, Nancy K.; and Pietrofesa, John J. "Perspectives on Counseling Bias: Implications for Counselor Education." The Counseling Psychologist IV(I) (1973) 441-454.

Schwartz, Mary C. "Importance of Sex of Worker and Client." Social Work 19(2) (March 1974): $177-186$. 
Staten, Betty. "The Effect of Counselor Gender and Sex-Role Attitudes on Change of Female Client's Sex-Role Attitudes." Guidance and Counseling (June 1974): 647A.

Steinman, A. "Perceptions of the Feminine Role Among Male Psychologists." International Mental Health Research Newsletter XIV(1) (Spring 1972): 6 .

Steinman, A. "Sex Role Bias in Psychotherapy." International Mental Health Research Newsletter XV (2) (Summer 1973): 8-12.

Summers, David A.; Faucher, Ted; and Chapman, Sue B. "A Note on Nonprofessional Judgements of Mental Health." Community Mental Health Journal 9(2) (Summer 1973): 169-177.

Szasz, T. S. "The Sane Slave: A Historical Note on the Use of Medical Diagnosis as Justificatory Rhetoric." American Journal of Psychotherapy 2J (1971): $228-239$.

Task Force Report of the APA. "Report of the Task Force on Sex Bias and Sex-Role Stereotyping in Psychotherapeutic Practice." American Psychologist (December 1975): 116 9-1175.

Thomas, A. H., and Stewart, N. R. "Counselor Response to Female Clients with Deviate and Conforming Career Goals." Journal of Counseling Psychology 18 (1971): $352-357$.

Zeldow, Peter B. "Clinical Judgement: A Search for Sex Differences." Psychological Report 37 (December 1975): 1135-1142.

\section{DISSERTATIONS}

Briggs, Barbara. "Effects of Sex-Role Awareness Training on Attitudes of Mental Health Professionals." Ph.D. dissertation. Northern Colorado University. 1975.

Burhenne, Diane Pollock. "Female and Male Evaluations of Sex-Appropriate and Sex-Inappropriate SexRole Stereotypes." Ph.D. Dissertation. Ohio State University. 1972. 
Chasen, Barbara. "Diagnostic Sex-Role Bias and Its Relation to Authoritarianism, Sex-Role Attitudes and Sex of the School Psychologist." Ph.D. dissertation. New York University. 1974.

Cripps, Rosalie Ann T. "The Influence of Sex-Role Stereotypes on Judgements of Emotional Disturbance." Ph.D. dissertation. University of Texas. 1973.

Fernoff, Deborah. "An Evaluation of Therapist Personality Traits, Therapist's Interpersonal Skills, and Therapist Sex." Ph.D. dissertation. Temple University. 1975.

Goldberg, Lorraine H. "Attitudes of Clinical Psychologists Towards Women." Ph.D. dissertation. Illinois Institute of Technology. 1973.

Gorske, John Philip. "Consequences of Typical and Atypical Sex-Role Behaviors for the Attribution of Personality Characteristics." $\mathrm{Ph}$.D. dissertation. University of California at Berkeley, 1972 .

Gun, Bonnie Rose. "A Study of the Effect of a SexRole Stereotype Workshop on Education: Students Attitudes Toward Women." Ph.D. dissertation. Boston University. 1975.

Hyink, Paul William. "The Influence of Client EgoStrength, Client Sex and Therapist Sex on the Frequency, Depth, and Focus of Client SelfDisclosure. Ph.D. dissertation. Michigan State University. 1974.

Johnson, Patricia I. "The Relationships Between SexRole Stereotypes and Concepts of Mental Health." Ph.D. dissertation. Arizona State University. 1974 .

Kennedy, Margaret Sandra I. "The Effect on Persuasability of the Client's Self-Esteem, His or Her Sex and the Sex of the Counselor." Ph.D. dissertation. MćGill University. 1975. 


\section{DISSERTATIONS}

Klein, Ruth R." "Sex-Role Stereotype Bias as Reflected in Counselors' Attitudes Towards Their Clients. Ph.D. dissertation. Indiana University. 1975.

Libbey, Mary D. "Sex-Stereotyping in Psychotherapist Responses in an Analogue Therapy Situation." Ph.D. dissertation. Columbia University. 1975.

Mann, Ronald Lewis. "Examination of Sex-Bias in the Evaluation of Diagnosis and Prognosis of Emotional Disturbance by Mental Health Professionals." Ph.D. dissertation. California school of Professional Psychology. 1974.

Naffziger, C., and Naffziger, K. G. "A Survey of Counselor-Educator's and other Selected Professional's Attitudes Towards Women's Roles. Ph.D. dissertation. University of Oregon. 1972.

Shapiro, Johanna F. "Socialization of Sex Roles in the Counseling setting: Differential Counselor Behavioral and Attitudinal Responses to Typical and Atypical Female Sex Roles." Ph.D. dissertation. Stanford University. 1975.

Williams, Grady Neil. "Effects of Interpersonal Atmosphere and Sex of Interviewer on Interview Related Behaviors. Ph.D. dissertation. University of Missouri-Columbia. 1969.

\section{UNPUBLISHED ARTICLES}

Abramowitz, S. I.; Abramowitz, C. V.; Roback, H. B.; and McKee, e. "Sex-Role Related Countertransference in Psychotherapy. Unpublished Manuscript. Vanderbilt University. 1974.

Benetato, J. "Females in Therapy: Sex-Role Restrictions." Unpublished manuscript, California State University. Northridge, California. 1973.

Fields, Rona M. "Psychotherapy: The Sexist Machine." KNOW reprint. Pittsburgh, Pennsylvania, 1-11. 
Herschel, Anne Marie. "Anti-Feminist Bias in Traditional Measurement of Masculinity-Femininity." Metting of Nat'1. Convention on Family Relations. Estes Park, Colorado. 1971.

Swartz, J. M., and Abramowitz, S. I. "Effects of Psychiatrist Values and Patient Race and Sex on Clinical Judgement." paper presented at the Meeting of the American Psychological Association. New Orleans, Louisiana. September 1974. 
APPENDIX A

COUNSELOR RESPONSE CATEGORIES 


\section{COUNSELOR RESPONSE CATEGORIES (Porter, 1955)}

Evaluative

Interpretive

Supportive

Probing

Understanding
A response that implies directly or indirectly (grossly or subtly) the relative goodness, appropriateness, effectiveness, or rightness of the client's behavior.

A response, the intent of which is to teach or impart some new meaning to the client.

A response which indicates that the intent is to reassure the client and perhaps thereby reduce the intensity of his feeling and/or discomfort.

A response which seems to gain further information or to provoke further exploration along a certain line.

A response which indicates that the counselor is trying to see if one understands correctly what the client is saying, how the client perceives the problem, or how the client is feeling. 
APPENDIX B

THE QUESTIONNAIRE 
Shari P. Greenberg 3101 S.W. 13th Ave. Apt. 5A

Portland, Oregon 97201

March 3, 1975

\section{Dear Clinician:}

My name is Shari Greenberg. I am a second year graduate student at the School of Social Work at Portland State University. Currently, I am studying the nature of the responses which clinicians have toward people undergoing psychotherapy. The subjects in my study are a random sample of social workers and licensed psychologists. You have been selected as part of this sample.

I would greatly appreciate your participation in this study. As in many studies of this nature, it is quite important for me to obtain a 100 level of response. Although this instrument may appear lengthy, it took the subjects in my pretest only fifteen minutes to complete. The responses, that you make will not be scored on a right or wrong basis, but rather they will provide a profile of the theraputic procedures which are presently favored. All responses to this questionnaire will be held in strictest confidence. An abstract, presenting the findings of this study, will be sent to all participants in the study.

Procedure: Three excerpts from interviews are presented. You are given a small anount of information about the background of the person speaking. You can assume that no further information on the case is available. Basically, you are ssked to respond in several ways to isolated client expressions. First you are asked to indicate what kinds of responses you favor from a list of many possible responses to each excerpt. The responses you will be rating are intended to represent broad response categories. Second you are asked to indicate the kind of aim or purpose you would most likely have in mind for the $20 \mathrm{i}$ client. Third you are asked to describe the client in a series of seven-point semantic differential items. And finally, there are a couple of questions as to how you feel about each client.

Thank you very much for your time and consideration. If you have any questions please call me at 233-2526 during the evening. I would appreciate your returning this questionnaire as soon as you possibly can.

Sincerely,

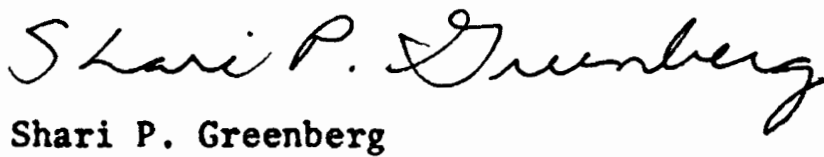


Age

Sex

Marital Status

Theoretical Orientation (School of Therapy)

Eclectic Gestalt Transactional Analysis

Behaviorism Rogerian Psychoanalytic

Other (Please specify)

Educational Background (Degrees) and Training

Length of Time in Practice 
Setting: This 26-year-old woman has been coming to therapy for two months. She received a $B A$ in Art History and she is presently working as a manager of an art gallery.

Therapist: "How are you today?"

Client: "I'm really not feeling very well still. I think I expected to feel much better by now. I know that you have a difficult job. Yet I still sometimes wonder what it is that is happening here. Right now I am feeling kind of cheated. It costs so much to see you. Sometimes I think that I might have felt better is I had spent the money on something more concrete like some new clothes or a vacation. I really don't see how telling you about my problems can help me. My friends will listen to my problems. I'm feeling that this is not helping me and I don't want to come anymore." 
How likely is it that you would make each of the following responses? Please keep in mind that the following responses are intended to represent broad response categories. In other words, rate the response according to whether it is the kind of response that you.would make, even if the choice of words is not precisely your own.

1. "Of course, whether or not you come to therapy has to be your decision. I cannot force you to come but I feel that you will not settle anything by backing away from it."

\begin{tabular}{lllll}
\hline $\begin{array}{l}\text { Extremely } \\
\text { Likely }\end{array}$ & $\begin{array}{l}\text { Somewhat } \\
\text { Likely }\end{array}$ & Neutral & $\begin{array}{l}\text { Somewhat }: \\
\text { Unlikely }\end{array}$ & $\begin{array}{l}\text { Extremely } \\
\text { Unlikely }\end{array}$
\end{tabular}

2. "I'd like to know more about how you came to this decision."

\begin{tabular}{lllll}
\hline Extremely & Somewhat & Neutral & Somewhat & Extremely \\
Likely & Likely & $\therefore:$. & Unlikely & Unlikely
\end{tabular}

3. "So therapy doesn't seem to be what you want right now."

\begin{tabular}{lllll}
\hline Extremely & Somewhat & Neutral & Somewhat & Extremely \\
Likely & Uikely & & Unlikely & Unlikely
\end{tabular}

4. "I think this experience has been painful for you and now you want to escape the situation which is producing the pain."

\begin{tabular}{lllll}
\hline $\begin{array}{l}\text { Extremely } \\
\text { Likely }\end{array}$ & $\begin{array}{l}\text { Somewhat } \\
\text { Likely }\end{array}$ & Neutral & Somewhat & $\begin{array}{l}\text { Extremely } \\
\text { Unlikely }\end{array}$ \\
Unlikely
\end{tabular}

5. "I know that therapy can be a difficult and demanding thing. Perhaps if you decided to continue coming we could reach a point where you could see more clearly what you are learning from this process."

\begin{tabular}{lllll}
\hline $\begin{array}{l}\text { Extremely } \\
\text { Likely }\end{array}$ & $\begin{array}{l}\text { Somewhat } \\
\text { Likely }\end{array}$ & Neutral & $\begin{array}{l}\text { Somewhat } \\
\text { Unlikely }\end{array}$ & $\begin{array}{l}\text { Extremely } \\
\text { Unlikely }\end{array}$
\end{tabular}

6. "I'm feeling angry right now. Perhaps we need to explore further your reactions to me and other people in your life."

\begin{tabular}{lllll}
\hline $\begin{array}{l}\text { Extremely } \\
\text { Likely }\end{array}$ & $\begin{array}{l}\text { Somewhat } \\
\text { Likely }\end{array}$ & Neutral & $\begin{array}{l}\text { Somewhat } \\
\text { Unlikely }\end{array}$ & $\begin{array}{l}\text { Extremely } \\
\text { Unlikely }\end{array}$
\end{tabular}


How likely is it that you would follow each of the following aims or purposes in this particular interview?

1. Indicate to the client that therapy is a long and difficult process for some people and that its benefits may become clearer as time progresses.

\begin{tabular}{lllll}
\hline Extremely & Somewhat & Neutral & $\begin{array}{l}\text { Somewhat } \\
\text { Unlikely }\end{array}$ & $\begin{array}{l}\text { Extremely } \\
\text { Unlikely }\end{array}$
\end{tabular}

2. Encourage the client to continue talking so the counselor can get a better idea of what to deal with in this case.

\begin{tabular}{lllll}
\hline Extremely & Somewhat & Neutral & $\begin{array}{l}\text { Somewhat } \\
\text { Unlikely }\end{array}$ & $\begin{array}{l}\text { Extremely } \\
\text { Unlikely }\end{array}$
\end{tabular}

3. Help the client to consider that her reaction may be in part due to her own attitudes.

\begin{tabular}{lllll}
\hline $\begin{array}{l}\text { Extremely } \\
\text { Likely }\end{array}$ & $\begin{array}{l}\text { Somewhat } \\
\text { Likely }\end{array}$ & Neutral & $\begin{array}{l}\text { Somewhat } \\
\text { Unlikely }\end{array}$ & $\begin{array}{l}\text { Extremely } \\
\text { Unlikely }\end{array}$
\end{tabular}

4. Convey to the client that is very natural that she feels the way she does: many clients go through a stage where they are very cynical about therapy.

\begin{tabular}{lllll}
\hline $\begin{array}{l}\text { Extremely } \\
\text { Likely }\end{array}$ & $\begin{array}{l}\text { Somewhat } \\
\text { Likely }\end{array}$ & Neutral & $\begin{array}{l}\text { Somewhat } \\
\text { Unlikely }\end{array}$ & $\begin{array}{l}\text { Extremely } \\
\text { Unlikely }\end{array}$
\end{tabular}

5. Reinforce the client in some way for expressing her feelings and needs.

\begin{tabular}{lllll}
\hline $\begin{array}{l}\text { Extremely } \\
\text { Likely }\end{array}$ & $\begin{array}{l}\text { Somewhat } \\
\text { Likely }\end{array}$ & Neutral & Somewhat & $\begin{array}{l}\text { Extremely } \\
\text { Unlikely }\end{array}$ \\
Unlikely
\end{tabular}


Describe how you see this client by marking the appropriate place on the scale.

1. Not at all aggressive Very aggressive 123 4 5 6 7

2. Not at all independent

Very independent

$\begin{array}{lllllll}1 & 2 & 3 & 4 & 5 & 6 & 7\end{array}$

3. Very emotional

Not at all emotional

\begin{tabular}{lllllll}
1 & 2 & 3 & 4 & 5 & 6 & 7 \\
\hline
\end{tabular}

4. Very tactful

Not at all tactful

$\begin{array}{llllll}2 & 3 & 4 & 5 & 6\end{array}$

5. Does not hide emotions at all

Almost always hides enotions

$\begin{array}{lllllll}2 & 2 & 3 & 4 & 5 & 6 & 7\end{array}$

6. Very subjective

Not at all subjective

\begin{tabular}{lllllll}
1 & 2 & 3 & 4 & 5 & 6 & 7 \\
\hline
\end{tabular}

7. Very easily influenced

Not at all easily influenced

\begin{tabular}{llllll}
1 & 2 & 3 & 5 & 6 & 7 \\
\hline
\end{tabular}

8. Very submissive

Very dominant

\begin{tabular}{lllllll}
1 & 2 & 3 & 4 & 5 & 6 & 7 \\
\hline
\end{tabular}

9. Very gentle

Very rough

$\begin{array}{llllll}2 & 3 & 4 & 5 & 6\end{array}$

10. Very aware of feelings of others Not at all aware of feelings

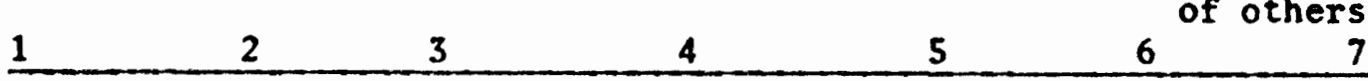

11. Very passive

Very active

\begin{tabular}{lllllll}
1 & 2 & 3 & 4 & 5 & 6 & 7 \\
\hline
\end{tabular}

12. Very illogical

Very logical

\begin{tabular}{lllllll}
1 & 2 & 3 & 5 & 6 & 7 \\
\hline
\end{tabular}

13. Has difficulty making decisions Can make decisions easily 1 3 4 5 6 
14. Very quiet

Very loud

1

2 3

4

5

6 7

15. Not at all self-confident

Very self-confident

$1 \quad 2$

16. Unable to separate feelings

from ideas

Easily able to separate 12

17. Very dependent

Not at all dependent $1 \quad 2$ $3 \quad 4$ Not at all uncomfortable about

18. Very uncomfortable about being aggressive being aggressive

1 3 4 5 6 7 
1. How serious a problem do you consider this person to have?

\begin{tabular}{lllll}
\hline Extremely & Very & Moderately & Slightly & Not at all \\
Serious & Serious & Serious & Sorious & Serious
\end{tabular}

2. How likely is it that you would choose this person as a client?

\begin{tabular}{lllll}
\hline Extremely & Somewhat & Neutral & Somewhat & Extremely \\
Likely & Likely & & Unlikely & Unlikely
\end{tabular}

3. How likely is it that you would find yourself irritated or annoyed with this person?

\begin{tabular}{lllll}
\hline $\begin{array}{l}\text { Extremely } \\
\text { Likely }\end{array}$ & $\begin{array}{l}\text { Somewhat } \\
\text { Likely }\end{array}$ & Neutral & $\begin{array}{l}\text { Somewhat } \\
\text { Unlikely }\end{array}$ & $\begin{array}{l}\text { Extremely } \\
\text { Unlikely }\end{array}$
\end{tabular}

4. How difficult would it be for you to respond to this person?

\begin{tabular}{lllll}
\hline Extremely & Very & Moderately & Slightly & Not at all \\
Difficult & Difficult & Difficult & Difficult & Difficult
\end{tabular}


Setting: This 45-year-old woman was referred to the therapist by a domestic relations court. She completed high school and is presently working as a sales clerk. She was recently divorced. This is her fourth session. She has just finished a long story about how horribly her husband treated her.

\section{Client: "We11?"}

Therapist: "Well, what?"

Client: Why don't you say something? You might, at least, express some sympathy. After all, I'm the one who has been hurt most by all this. You know that You should feel sorry for me. I cone here every week and tell you about the most intimate things in my life. I stru-gle to let out all my feelings and paing and you just sit back in your chair, relaxed, and listen like you were watching some boring, lousy soap opera monologue. Do you ever feel anything?" 
How likely is it that you would make each of the following responses? Please keep in mind that the following responses are intended to represent broad response categories. In other words, rate the response according to whether it is the kind of response that you would make, even if the choice of words is not precisely your own.

1. "So you don't feel that I'm sharing enough with you. You are angry because I don't respond like you think I should."

\begin{tabular}{|c|c|c|c|c|}
\hline $\begin{array}{l}\text { Extremely } \\
\text { Likely }\end{array}$ & $\begin{array}{l}\text { Somewha } \\
\text { Likely }\end{array}$ & Neutral & $\begin{array}{l}\text { Somewhat } \\
\text { Unlikely }\end{array}$ & $\begin{array}{l}\text { Extremely } \\
\text { Unlikely }\end{array}$ \\
\hline
\end{tabular}

2. "I think it is good that you are finally getting some anger out. I can see why you are angry with me. What can I do differently that might help you feel more comfortable with me?"

\begin{tabular}{lllll}
\hline Extremely & Somewhat & Neutral & Somewhat & Extremely \\
Likely & Likely & & Unlikely & Unlikely
\end{tabular}

3. "You want me to be angry with you. It seems like you seek this from other people too."

\begin{tabular}{lllll}
\hline Extremely & $\begin{array}{l}\text { Somewhat } \\
\text { Likely }\end{array}$ & Neutral & Somewhat & Extremely \\
Unlikely & Unlikely
\end{tabular}

4. "I'm feeling angry right now. Perhaps we need to explore further your reactions to me and other people in your life."

\begin{tabular}{lllll}
\hline Extremely & Somewhat & Noutral & $\begin{array}{l}\text { Somewhat } \\
\text { Likely }\end{array}$ & $\begin{array}{l}\text { Extremely } \\
\text { Unlikely }\end{array}$
\end{tabular}

5. "I'd like to know more about how you came to feel this way about me. Is this feeling a very familiar one with you?

\begin{tabular}{lllll}
\hline $\begin{array}{l}\text { Extremely } \\
\text { Likely }\end{array}$ & $\begin{array}{l}\text { Somewhat } \\
\text { Likely }\end{array}$ & Neutral & $\begin{array}{l}\text { Somewhat } \\
\text { Unlikely }\end{array}$ & $\begin{array}{l}\text { Extremely } \\
\text { Unlikely }\end{array}$
\end{tabular}

6. "I'm feeling stuck. It seems to me that anything I say right now won't satisfy you."

\begin{tabular}{lllll}
\hline $\begin{array}{l}\text { Extremely } \\
\text { Likely }\end{array}$ & $\begin{array}{l}\text { Somewhat } \\
\text { Likely }\end{array}$ & Neutral & $\begin{array}{l}\text { Somewhat } \\
\text { Unlikely }\end{array}$ & $\begin{array}{l}\text { Extremely } \\
\text { Unlikely }\end{array}$
\end{tabular}


How likely is it that you would follow each of the following aims or purposes in this particular interview?

1. Indicate to the client that therapy is a long and difficult process for some people and that its benefits may become clearer as time progresses.

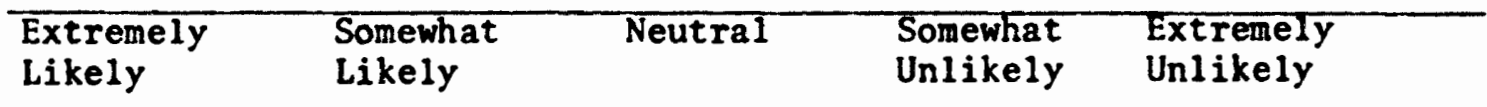

2. Encourage the client to continue talking so the therapist can get a better idea of what to deal with.

\begin{tabular}{lllll}
\hline Extremely & Somewhat & Neutral & Somewhat & Extremely \\
Likely & Likely & & Unlikely & Unlikely
\end{tabular}

3. Indicate an understanding of the client?s feelings.

\begin{tabular}{lllll}
\hline Extremely & $\begin{array}{l}\text { Somewhat } \\
\text { Likely }\end{array}$ & Neutral & $\begin{array}{l}\text { Somewhat } \\
\text { Un1ikely }\end{array}$ & $\begin{array}{l}\text { Extremely } \\
\text { Unlikely }\end{array}$
\end{tabular}

4. Convey to the client that it is very natural to feel the way she does: many clients find it difficult to understand what therapy is and how it works.

\begin{tabular}{lllll}
\hline $\begin{array}{l}\text { Extremely } \\
\text { Likely }\end{array}$ & $\begin{array}{l}\text { Somewhat } \\
\text { Likely }\end{array}$ & Neutral & $\begin{array}{l}\text { Somewhat } \\
\text { Unlikely }\end{array}$ & $\begin{array}{l}\text { Extremely } \\
\text { Unlikely }\end{array}$
\end{tabular}

5. Help the client to consider that her reactions may be in part due to her own attitudes.

\begin{tabular}{lllll}
\hline Extremely & Somewhat & Neutral & Somewhat & Extremely \\
Likely & Likely & & Unlikely & Unlikely
\end{tabular}

6. Reinforce the client for expressing her feelings and needs.

\begin{tabular}{lllll}
\hline Extremely & $\begin{array}{l}\text { Somewhat } \\
\text { Likely }\end{array}$ & Neutral & $\begin{array}{l}\text { Somewhat } \\
\text { Unlikely }\end{array}$ & $\begin{array}{l}\text { Extremely } \\
\text { Unlikely }\end{array}$
\end{tabular}


Describe how you see this client by marking the appropriate place on the scale.

1. Not at all aggressive

Very aggressive

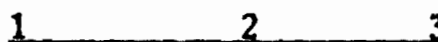

$3 \quad 4$ 5 6

Very independent

2. Not at all independent 5 7

3. Very emotional Not at all emotional

\begin{tabular}{lllllll}
1 & 2 & 3 & 4 & 5 & 6 & 7 \\
\hline
\end{tabular}

4. Very tactful

Not at all tactful

$\begin{array}{lllllll}1 & 2 & 3 & 4 & 5 & 6 & 7\end{array}$

5. Does not hide emotions at all

Almost always hides emotions

\begin{tabular}{lllllll}
1 & 2 & 3 & 4 & 5 & 6 & 7 \\
\hline
\end{tabular}

6. Very subjective

Not at all subjective

\begin{tabular}{lllllll}
1 & 2 & 3 & 4 & 5 & 6 & 7 \\
\hline
\end{tabular}

7. Very easily influenced

Not at all easily influenced 1 3 4 5 6 7

8. Very submissive

Very dominant

\begin{tabular}{lllllll}
1 & 2 & 3 & 4 & 5 & 6 & 7 \\
\hline
\end{tabular}

9. Very gentle

Very rough

$\begin{array}{lllllll}1 & 2 & 3 & 4 & 5 & 6 & 7\end{array}$

10. Very aware of feelings of others Not at all aware of feelings 1 3 45 of others

11. Very passive Very active 1 2 3 4 5 7

12. Very illogical Very logical \begin{tabular}{lllllll}
1 & 2 & 3 & 4 & 5 & 6 & 7 \\
\hline
\end{tabular} 13. Has difficulty making decisions Can make decisions easily 1 2 3 4 5 6 7 
14. Very quiet

Very loud

1

23

4

5

6

7

15. Not at all self-confident

Very self-confident

1 $2 \quad 3$

4 5 6 7

16. Unable to separate feelings from ideas

Easily able to separate feelings from ideas 1

17. Very dependent Not at all dependent 1 23 4 5 6 7

18. Very uncomfortable about being aggressive

Not at all uncomfortable about 1 3 4 being aggressive 2

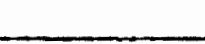


1. How serious a problem do you consider this person to have?

\begin{tabular}{lllll}
\hline Extremely & Very & Moderately & Slightly & Not at all \\
Serious & Serious & Serious & Serious & Serious
\end{tabular}

2. How likely is it that you would choose this person as a client?

\begin{tabular}{lllll}
\hline Extremely & $\begin{array}{l}\text { Somewhat } \\
\text { Likely }\end{array}$ & Neutral & Somewhat & $\begin{array}{l}\text { Extremely } \\
\text { Unlikely }\end{array}$
\end{tabular}

3. How likely is it that you would find yourself irritated or annoyed with this person?

\begin{tabular}{lllll}
\hline Extremely & Somewhat & Neutral & Somewhat & Extremely \\
Likely & Unlikely & & Unlikely
\end{tabular}

4. How difficult would it be for you to respond to this person?

\begin{tabular}{lllll}
\hline Extremely & Very & Moderately & Slightly & Not at all \\
Difficult & Difficult & Difficult & Difficult & Difficult
\end{tabular}


Setting: This 22-year-old single woman has been coming to therapy for three months. She went to college for two years and dropped out. She has been working at odd jobs since college usually making only subsistence wages.

Client: "I'm really feeling awful these days. I don't care about anything and $I$ don't feel like doing anything. I can't even stand to eat anymore. My mother is really worried about me. She has been coming over to my house and fixing me things to eat lately. I'm thinking of moving back home now because all $I$ do is sleep all the time and I'm afraid sometimes that I might not wake up. I need someone to look after me right now. I hope that you don't get sick or anything because I don't know what I would do if I couldn't see you every week. Seeing you is practically the only thing I can get up for these days. Are you going to tell me how to get better?" 
How likely is it that you would make each of the following responses? Please keep in mind that the following responses are intended to represent broad response categories. In other words, rate the response according to whether it is the kind of response that you would make, even if the choice of words is not precisely your own.

1. "You sound very discouraged and hopeless. You're feeling that 'you can't help yourself right now and you want someone to sake cate couyou."

\begin{tabular}{|c|c|c|c|}
\hline $\begin{array}{l}\text { Extremely } \\
\text { Likely }\end{array}$ & $\begin{array}{l}\text { Somewhat } \\
\text { Likely }\end{array}$ & Neutral & $\begin{array}{l}\text { Somewhat } \\
\text { Unlikely }\end{array}$ \\
\hline
\end{tabular}

2. "Perhaps one of the important aspects of your situation is that you don't have any real confidence in yourself. Do you see this?"

\begin{tabular}{|c|c|c|c|c|}
\hline $\begin{array}{l}\text { Extremely } \\
\text { Likely }\end{array}$ & $\begin{array}{l}\text { Somewhat } \\
\text { Likely }\end{array}$ & Neutral & $\begin{array}{l}\text { Somewhat } \\
\text { Unlikely }\end{array}$ & $\begin{array}{l}\text { Extremely } \\
\text { Unlikely }\end{array}$ \\
\hline
\end{tabular}

3. "I need to have a lot more information about you before I can answer you satisfactorily. I need you to talk more about your childhood, your family, your work, the important relationships in your life, and so on."

\begin{tabular}{lllll}
\hline Extremely & Somewhat & Neutral & Somewhat & Extremely \\
Likely & Likely & & Unlikely & Unlikely
\end{tabular}

4. "I'm feeling overwhelmed by the responsibility you seem to be giving me for your life. Only you can help yourself. I can only help you learn to help yourself. I think you need to learn how to trust your own feelings and to make your own decisions."

$\begin{array}{lllll}\text { Extremely } & \text { Somewhat } & \text { Neutral } & \text { Somewhat } & \text { Extremely } \\ \text { Likely } & \text { Likely } & & \text { Unlikely } & \text { Unlikely }\end{array}$

5. "You certainly have asked me to do alot. The best answer that I can give is this: We will work together on the things that are bothering you. Hopefully, between the two of us, we will be able to figure out what's happening with you and begin to explore the alternatives you have. Meanwhile, I would not worryalot about it. I think we can be pretty confident about making some progress."

$\begin{array}{lllll}\text { Extremely } & \text { Somewhat } & \text { Neutral } & \text { Somewhat } & \text { Extremely } \\ \text { Likely } & \text { Likely } & & \text { Unlikely } & \text { Unlikely }\end{array}$


How likely is it that you would follow each of the following aims or purposes in this particular interview?

1. Ask the client to discuss why she has such a low estimate of herself.

\begin{tabular}{lllll}
\hline Extremely & Somewhat & Neutral & $\begin{array}{l}\text { Somewhat } \\
\text { Unlikely }\end{array}$ & $\begin{array}{l}\text { Extremely } \\
\text { Unlikely }\end{array}$
\end{tabular}

2. Communicate to the client your understanding that she feels pretty hopeless and depressed about her situation.

\begin{tabular}{lllll}
\hline Extremely & $\begin{array}{l}\text { Somewhat } \\
\text { Likely }\end{array}$ & Neutral & $\begin{array}{l}\text { Somewhat } \\
\text { Unlikely }\end{array}$ & $\begin{array}{l}\text { Extremely } \\
\text { Unlikely }\end{array}$
\end{tabular}

3. Encourage the client to continue talking so you can get a better idea of what to deal with.

\begin{tabular}{lllll}
\hline $\begin{array}{l}\text { Extremely } \\
\text { Likely }\end{array}$ & $\begin{array}{l}\text { Somewhat } \\
\text { likely }\end{array}$ & Neutral & $\begin{array}{l}\text { Somewhat } \\
\text { Unlikely }\end{array}$ & $\begin{array}{l}\text { Extremely } \\
\text { Unlikely }\end{array}$
\end{tabular}

4. Get over to the client that even though she presently lacks self-confidence she can learn how to assert herself better by doing certain exercises in therapy that the therapist suggests.

\begin{tabular}{lllll}
\hline Extremely & Somewhat & Neutral & Somewhat & Extremely \\
Likely & Likely & & Unlikely & Unlikely
\end{tabular}

5. Reinforce the client for expressing her feelings and needs.

\begin{tabular}{lllll}
\hline $\begin{array}{l}\text { Extremely } \\
\text { likely }\end{array}$ & $\begin{array}{l}\text { Somewhat } \\
\text { Likely }\end{array}$ & Neutral & $\begin{array}{l}\text { Somewhat } \\
\text { Unlikely }\end{array}$ & $\begin{array}{l}\text { Extremely } \\
\text { Unlikely }\end{array}$
\end{tabular}


Describe how you see this client by marking the appropriate place on the scale.

1. Not at all aggressive Very aggressive 12 $3 \quad 4$ 5 6 7

2. Not at all independent Very independent \begin{tabular}{lllllll}
1 & 2 & 3 & 4 & 5 & 6 & 7 \\
\hline
\end{tabular}

3. Very emotional Not at all emotional

\begin{tabular}{lllllll}
1 & 2 & 3 & 4 & 5 & 6 & 7 \\
\hline
\end{tabular}

4. Very tactful

Not at all tactful

$\begin{array}{lllllll}1 & 2 & 3 & 4 & 5 & 6 & 7\end{array}$

5. Does not hide emotions at all

Almost always hides emotions

\begin{tabular}{lllllll}
1 & 2 & 3 & 4 & 5 & 6 & 7 \\
\hline
\end{tabular}

6. Very subjective

Not at all subjective

\begin{tabular}{lllllll}
1 & 2 & 3 & 4 & 5 & 6 & 7 \\
\hline
\end{tabular}

7. Very easily influenced

Not at all easily influenced $1 \quad 2 \quad 3$ $4 \quad 5$ 6 7

8. Very submissive

Very dominant 1 3 4 5 7

9. Very gentle

Very rough

1 $2 \quad 3$ 4 5 6 7

10. Very aware of feelings of others Not at all aware of feelings

\begin{tabular}{llllll}
1 & 2 & 3 & 4 & & of others \\
\hline
\end{tabular}

11. Very passive Very active 1 2 3 4 5 7

12. Very illogical Very logical 1 2 3 4 5 6 7

13. Has difficulty making decisions Can make decisions easily 1 3 4 5 6 7 
14. Very quiet

Very loud

\begin{tabular}{lllllll}
1 & 2 & 3 & 4 & 5 & 6 & 7 \\
\hline
\end{tabular}

15. Not at all self-confident

Very self-confident

\begin{tabular}{lllllll}
1 & 2 & 3 & 4 & 5 & 6 & 7 \\
\hline
\end{tabular}

16. Unable to separate feelings from ideas

Easily able to separate feelings from ideas

\begin{tabular}{llll}
1 & 2 & 3 & 4 \\
\hline
\end{tabular}

17. Very dependent

Not at all dependent

\begin{tabular}{lllllll}
1 & 2 & 3 & 4 & 5 & 6 & 7 \\
\hline
\end{tabular}

18. Very uncomfortable about being aggressive

Not at all uncomfortable about being aggressive

$\begin{array}{llllll}1 & 2 & 3 & 4 & 5 & 6\end{array}$


1. How serious a problem do you consider this person to have?

\begin{tabular}{lllll}
\hline Extremely & Very & Moderately & Slightly & Not at all \\
Serious & Serious & Serious & Serious & Serious
\end{tabular}

2. How likely is it that you would choose this person as a client?

\begin{tabular}{lllll}
\hline Extremely & $\begin{array}{l}\text { Somewhat } \\
\text { Likely }\end{array}$ & Neutral & Somewhat & Extremely \\
Likely & & Unlikely & Unlikely
\end{tabular}

3. How likely is it that you would find yourself irritated or annoyed with this person?

\begin{tabular}{lllll}
\hline Extremely & Somewhat & Neutral & Somewhat & Extremely \\
Likely & Unlikely & & Unlikely & Unlikely
\end{tabular}

4. How difficult would it be for you to respond to this person?

\begin{tabular}{lllll}
\hline Extremely & Very & Moderately & Slightly & Not at all \\
Difficult & Difficult & Difficult & Difficult & Difficult
\end{tabular}

